\title{
WHY LICENSE AgREEMENTS Do NOT CONTROL COPY OWNERSHIP: FIRST SALES AND ESSENTIAL COPIES
}

\author{
Brian W. Carver
}

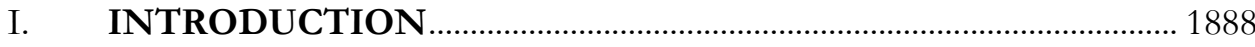

II. THE FIRST SALE DOCTRINE (\$ 109) AND \$ 117 .......................... 1891

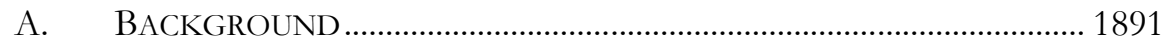

B. THE PROBlem Posed BY MDY INDUSTRIES LLC $V$.

BLIZZARD ENTERTAINMENT, INC...................................................... 1892

C. THE Distinction BeTWEen the INTANGiBle Copyright

AND THE TANGIBLE COPY .............................................................. 1896

III. WHEN DOES TITLE TO A COPY PASS TO THE

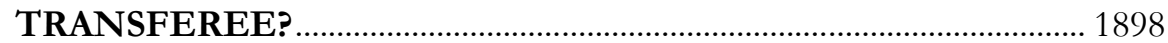

A. The Reservation Of TITLE APPROACH ......................................... 1899

1. The "Magic Words" Cases: MAI Systems Corp. v. Peak

Computer, Inc. and Microsoft Corp. v. Harmony

Computers \& Electronics, Inc........

2. Wall Data Inc. v. L.A. County Sheriff's Department and

S.O.S. Inc. v. Payday, Inc........................................................... 1902

B. The AgreEMENT CONTROLS APPROACH ..................................... 1905

1. DSC Communications Corp. v. Pulse

Communications, Inc. 1906

2. Novell, Inc. v. CPU Distributing, Inc. and Novell, Inc.

v. Unicom Sales, Inc. ……………………………………......... 1908

3. MDY Industries LLC v. Blizzard Entertainment, Inc........... 1911

4. Vernor v. Autodesk, Inc. (9th Circuit panel).............................. 1912

C. THE UNiform COMMERCIAL CODE CONTROLS APPROACH ......... 1914

D. THE ECONOMIC REALITIES APPROACH.............................................. 1915

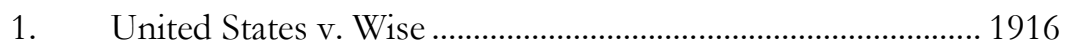

2. Microsoft Corp. v. DAK Industries .......................................... 1916

3. Krause v. Titleserv, Inc.: The "Incidents of Ownership"............... 1918

E. The PERPETUAL PosSession APPROACH........................................... 1920

1. UMG Recordings, Inc. v. Augusto ………………………….... 1920

C 2010 Brian W. Carver.

† Brian W. Carver, Assistant Professor, University of California, Berkeley, School of Information. J.D., University of California, Berkeley School of Law (Boalt Hall). 
2. Vernor v. Autodesk, Inc. (district court)

IV. THE $A D O B E$ OPINIONS AND INTERPRETIVE

DIFFICULTY

V. CHARACTERISTICS OF A CORRECT APPROACH TO

DETERMINING COPY OWNERSHIP ............................................ 1930

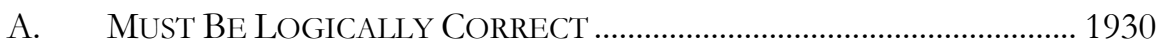

1. Must Not Equivocate with Respect to the Words "License" or "Software".

2. Must Recognize the Possibility of Ownership of a Copy

Independent from Ownership of the Copyright. 1935

3. Must Not Look to Factors that are Wholly Orthogonal to Resolving the Issue of Copy Ownership 1937

a) Copyright Permissions are Irrelevant to a

Determination of Copy Ownership 1937

b) Particularly Problematic Permissions ............................ 1939

B. MUST RESPECT PRECEDENT ………………................................. 1939

1. Must Respect Supreme Court Precedent and Should Seek to

Harmonize Circuit Court Precedents.

2. Should Heed the Warning of the Supreme Court's Recent

Quanta Computer Decision

C. Must RESPECT CONGRESSIONAL CHOICES.

D. Must TAKE INTO ACCOUNT THAT THE COPYRIGHT ACT

EXPLICITLY ENUMERATES THOSE METHODS OF

DisTRIBUTION WITHIN THE EXCLUSIVE RIGHTS OF

COPYRIGHT OWNERS AND A DISTRIBUTION IN WHICH

TITLE TO THE COPY IS RESERVED IS NOT AMONG THEM. 1945

1. Must Recognize the Limiting Role Played by IS 107 Through

122 and Examine Whether Contrary Contractual Provisions

are Federally Preempted..

2. Should Preserve as Far as Possible the National Uniformity

Copyright Law Seeks. 1951

VI. HOW TO ADDRESS MDY INDUSTRIES LLC V. BLIZZARD ENTERTAINMENT, INC. 1953

VII. CONCLUSION 1954

\section{INTRODUCTION}

This Article argues for an analytic approach to determine ownership of a tangible copy of a copyrighted work. Courts have been surprisingly divided on this apparently simple question and have employed several distinct and conflicting approaches, sometimes within the same Circuit. 
That courts resolve the issue of copy ownership predictably is important for at least five reasons. First, only those who are "owners" of a copy are entitled to exercise the important rights of 17 U.S.C. $\int 109$ and $\int 117,{ }^{1}$ the first sale rights, and the right to make essential-step copies and adaptations of computer programs, respectively. Both sections play a critical role in efforts by Congress to create a system of copyright that achieves a balance between the exclusive rights given to a copyright owner and the rights reserved for the user of a copyrighted work. Without a consistent approach to determine copy ownership, users of copyrighted works cannot exercise rights under \109 and $\int 117$ without uncertainty and a fear of liability.

Second, as illustrated by the district court opinion in MDY Industries LLC v. Blizard Entertainment, Inc., ${ }^{2}$ the question of copy ownership can be determinative of whether a third party distributor of interoperable software is liable for secondary copyright infringement. If the approach to copy ownership taken by the MDY Industries district court is adopted by more courts, copyright owners' monopolies may be limited only by the imaginativeness of their end-user license agreements ("EULAs"). Thus, relying on a misguided approach to copy ownership enables copyright misuse of sweeping proportions. ${ }^{3}$

Third, the current practice in software licensing of asserting that the distributor "licenses but does not sell" its software is logically incoherent. Software distributors make this assertion in order to preserve the argument that the software users - even those with a right to perpetual possession of the tangible copy-are not "owners" of the copy and thus cannot exercise rights under $\int 109$ and $\int 117$. If software distributors knew that they could not succeed in such claims, those distributors that had a true business need to prevent either downstream sales or $\int 117$ copies would be incentivized to adopt a rental or leasing model. The result would be greater clarity and, potentially, economic benefits for both the distributor and the users.

Fourth, exhaustion principles such as the first sale doctrine embodied in \109 have promoted access to knowledge, preservation of culture, and resistance to censorship. In addition, these principles have provided the basis for secondary markets that have increased beneficial competition, have served to curtail inefficient and unfair price discrimination, and have long served to decrease the information cost of ascertaining restrictions on

1. 17 U.S.C. $\int 109$ (a) (2006) (limiting the rights of $\int 109$ to "the owner of a particular copy ... lawfully made"); 17 U.S.C. $\int 117$ (a) (2006) (limiting the rights of $\int 117$ to "the owner of a copy of a computer program").

2. No. CV-06-2555-PHX-DGC, 2008 WL 2757357 (D. Ariz. July 14, 2008).

3. See generally Lasercomb Am., Inc. v. Reynolds, 911 F.2d 970, 974-77 (4th Cir. 1990). 
tangible goods. Consequently, exhaustion has reconciled copyright law with property law policies that disfavor restraints on alienation. ${ }^{4}$ But since the first sale rights of $\int 109$ are only available to owners of a copy, uncertainty and inconsistency in the adjudication of copy ownership necessarily creates uncertainty and inconsistency in the adjudication of first sale rights. As a result, these beneficial effects are at risk of being diminished or lost.

Fifth, the questions addressed in determining copy ownership are often related to a larger debate concerning whether mass consumer contracts should trump the policies embodied in statutory schemes enacted by Congress. Public policy rationales favoring freedom to contract collide with the realities of non-negotiated boilerplate EULAs that purport to restrict statutory rights. Users have grown accustomed to these rights, and Congress intended that they have them as part of its larger effort to craft a balanced Copyright Act. Inconsistently resolving the issue of copy ownership thus muddles an already difficult question.

This Article proceeds in five parts. Part II provides background information on $\ 109$ and $\ 117$ and gives context for the Article's arguments regarding licensing, detailed in subsequent Parts. Part III reviews the various approaches courts and commentators have adopted regarding the determination of copy ownership. Part IV presents a case study of three Adobe cases decided in the same circuit. Part $\mathrm{V}$ proposes three essential features to a proper approach for determining copy ownership: logical consistency, respect of precedent, and respect for congressional choices. It also criticizes the other approaches taken by courts and argues that the Perpetual Possession approach (i.e., the right to perpetual possession of a copy is the primary, if not the dispositive factor in determining copy ownership) has all three essential features. Part VI applies the Perpetual Possession approach to the facts of MDY Industries in order to demonstrate why the district court's holding on copy ownership was erroneous. ${ }^{5}$

4. See Brief of Amici Curiae American Library Ass'n et al. in Support of Plaintiff \& Affirmance, Vernor v. Autodesk, Inc., 621 F.3d 1102 (9th Cir. 2009) (No. 09-35969), available at http://www.eff.org/files/filenode/vernor_v_autodes/VernorAmicus.pdf; Brief of Amici Curiae of Consumers Union (CU), Electronic Frontier Foundation (EFF), \& Public Knowledge in Support of the Petitioner, Quanta Computer, Inc. v. LG Electronics, Inc., 553 U.S. 617 (2008) (No. 06-937), available at http://www.eff.org/files/filenode/quanta_v_lg/ quanta_amicus.pdf.

5. The Ninth Circuit reversed the district court's holding on secondary copyright liability on other grounds, discussed infra Section II.B, while reaching the same erroneous result on the copy ownership issue. See MDY Indus. LLC v. Blizzard Entm't, Inc., 629 F.3d 928 (9th Cir. 2010). 


\section{THE FIRST SALE DOCTRINE (\$ 109) AND $\$ 117$}

\section{A. BACKGROUND}

Copyright law seeks a balance between the exclusive rights given to a copyright owner and the rights reserved for the user of a copyrighted work. ${ }^{6}$ Section 106 enumerates those exclusive rights of reproduction, modification, distribution, public display, and public performance, but it first states that those exclusive rights are "[s]ubject to" the limitations and exceptions found in $\iint 107$ through 122, such as fair use and first sale. ${ }^{7}$ Thus, these limitations and exceptions do not encroach upon the rightful domain of the copyright owner but instead serve to define the very scope of the exclusive rights of copyright in the first instance. Sections 107 through 122 reflect public rights created through the operation of law, not permissible acts subject to the authority of a copyright owner. That is, no one needs a license to make a fair use; everyone already has a right of fair use.

The public's expectations regarding a balanced copyright system integrally involve the first sale doctrine expressed in \$ 109 . Even before the doctrine was enshrined in the copyright statute, it was recognized by the Supreme Court of the United States in Bobbs-Merrill Co. v. Straus, in which the Court rejected a book publisher's attempt to restrict resale of a book by printing a notice in the front of the book that purported to prohibit sales for less than one dollar. ${ }^{8}$

The balance struck has thus long been that a copyright owner is entitled to reap her reward on the first sale of a copyrighted work, but that after such a sale, downstream owners of copies are free to sell or otherwise dispose of the possession of that copy however they see fit without needing any permission from the copyright owner. As a consequence, we have libraries, we have second-hand booksellers, and we can loan copies of books to friends, all without the requirement of a cumbersome request for permission from the copyright owner.

The Third Circuit noted in 1991 how the first sale doctrine came into conflict with software sales as home computing took off in the 1980s. ${ }^{9}$ The court explained that under the first sale doctrine, one could purchase a copy of a computer program and then lease or lend it to another without infringing the copyright on the program. Software producers feared that

6. Stewart v. Abend, 495 U.S. 207, 228 (1990); Sony Corp. of Am. v. Universal City Studios, Inc., 464 U.S. 417, 429 (1984).

7. 17 U.S.C. $\int 106(2006)$.

8. 210 U.S. 339 (1908).

9. See Step-Saver Data Sys. v. Wyse Tech., 939 F.2d 91, 96 n.7 (3d Cir. 1991). 
software rental stores comparable to video rental stores would become commonplace, and then, because of the ease of copying software, consumers would simply rent and duplicate software rather than purchase their own copy of the program. ${ }^{10}$ Congress addressed this concern by enacting the Computer Software Rental Amendments Act of 1990, ${ }^{11}$ which amended $\$ 109$ to forbid the unauthorized rental, lease, or lending of copies of computer programs for the purposes of direct or indirect commercial advantage except by non-profit libraries and non-profit educational institutions. $^{12}$

However, Congress was not merely responsive to the concerns of the software industry but also to the needs of users. It enacted $\int 117$ to enable the owners of copies of copyrighted computer programs to make certain types of copies and adaptations of that program essential to its use ${ }^{13}$ :

[n] otwithstanding the provisions of section 106, it is not infringement for the owner of a copy of a computer program to make or authorize the making of another copy or adaption of that computer program provided] that such a new copy or adaption is created as an essential step in the utilization of the computer program .... ${ }^{14}$

Thus, just as one does not need a license to make a fair use, an owner of a copy of a computer program does not need a license to make "essential step" copies. Every owner of a copy already has that right under $\int 117$.

\section{B. The Problem Posed by MDY Industries LlC V. Blizzard}

\section{ENTERTAINMENT, INC.}

The district court decision in MDY Industries tellingly illustrates the harm that can result from allowing copyright owners to leverage their copyright in an effort to control matters outside the scope of their exclusive rights under the Copyright Act.

Blizzard had to tell a very complex story to explain why MDY should be held liable for contributory copyright infringement. Blizzard distributes copies of World of Warcraft ("WoW"), a multiplayer online game, at most software and video game retailers for a one-time fee. ${ }^{15}$ Players also pay a

10. Id.

11. Computer Software Rental Amendments Act of 1990, Pub. L. No. 101-650, tit. VIII, 104 Stat. 5134, 5134-37.

12. 17 U.S.C. $\int 109$ (b) (2006).

13. Bayh-Dole Act, Pub. L. No. 96-517, \10(b), 94 Stat. 3015, 3028-29 (1980) (amending 17 U.S.C. $\$ 117$ to substantially its present form).

14. 17 U.S.C. $\int 117$ (a)(1) (2006).

15. World of Warcraft: Wrath of the Lich King, was available from http://www.bestbuy.com for $\$ 39.99$ on July 10, 2009. Note that Blizzard's "Quick Start 
monthly fee for online access. ${ }^{16}$ MDY sold "Glider," a software program called a "bot" that automated play of WoW. Glider automated repetitive, time-intensive parts of WoW, allowing a player's in-game character to more quickly reach the highest level, which then provides such characters with access to advanced game content that is not otherwise available. Many players have several characters at once, and Glider allowed them to develop these additional characters without replaying certain time-consuming portions of the game. ${ }^{17}$ Glider was not a cracking or hacking tool and it did nothing to enable making copies of WoW that was not already possible. Blizzard instead complained that it was entitled to design its game in a way that prevented "skip[ping] to the end"18 and that numerous WoW players had complained to them about the presence of Glider users in the game. ${ }^{19}$

For most software, including WoW, a user's computer makes a copy of at least portions of the software into its Random Access Memory ("RAM") whenever the program is used. RAM copies have been held to be infringements of the copyright holder's exclusive right to make copies. ${ }^{20}$ However, RAM copies made from a copy owned by the user are permitted under $\int 117$; for non-owners, copies incidental to use might be permitted under a provision in the EULA (if such a provision is present).

Guide" describing a downloadable ten-day free trial says, "You may upgrade your account at any time to a full version by purchasing a retail copy of the game at most software and video game retailers." Blizzard Entm't, Inc., Quick Start Guide, WORLD OF WARCRAFT, https://signup.worldofwarcraft.com/trial/qs5.html (last visited Jun. 30, 2009) (emphasis added) (on file with author).

16. Available in most countries are a month-to-month package at $\$ 14.99$ per month, a three-month plan at $\$ 13.99$ per month, and a six-month plan at $\$ 12.99$ per month. Blizzard Entm't, Inc., General FAQ, WORLD OF WARCRAFT, http://www.worldofwarcraft.com/info/ faq/general.html (last visited Nov. 23, 2010). The subscription fees for the three-month plan and the six-month plan must be paid in full at the beginning of the period. See id.

17. See First Brief on Cross Appeal at 5-7, MDY Indus. LLC v. Blizzard Entm't, Inc., 629 F.3d 928 (9th Cir. 2010) (Nos. 09-15932 \& 09-16044).

18. Response Brief of Appellees \& Opening Brief of Cross-Appellants at 64, MDY Indus. LLC, 629 F.3d 928 (Nos. 09-15932 \& 09-16044).

19. See Blizzard Entertainment, Inc. \& Vivendi Games, Inc. Motion for Summary Judgment \& Memorandum of Points \& Authorities in Support at 20-21, MDY Indus. LLC v. Blizzard Entm't, Inc., No. 06-02555 (D. Ariz. Mar. 21, 2008) [hereinafter Motion for Summary Judgment] (listing examples of user complaints).

20. MAI Sys. Corp. v. Peak Computer, Inc., 991 F.2d 511, 517-19 (9th Cir. 1993). But cf. Cartoon Network, LP v. CSC Holdings, Inc., 536 F.3d 121, 127-30 (2d Cir. 2008) (declining to read MAI Systems as holding that, as a matter of law, loading a program into a form of RAM always results in copying); Aaron Perzanowski, Fixing RAM Copies, 104 Nw. U. L. REV. 1067 (2010) (suggesting that, in addition to durational persistence, courts should consider the extent to which RAM instantiations serve as functional substitutes for traditional copies before classifying those instantiations as copies that implicate the reproduction right). 
WoW is governed by a EULA and a Terms of Use ("TOU”) that players must agree to before playing. These agreements now forbid, among other things, the use of bots. ${ }^{21}$ Blizzard alleged that users of WoW were not owners of their copies. Thus, Blizzard argued that the incidentally created RAM copies were permissible only by the terms of the EULA and the TOU and not under $\int 117$. Following this argument, when users launched WoW using Glider, they exceeded the license in the EULA and TOU and created infringing copies of the game client software in their computers' RAM. ${ }^{22}$ Thus, in Blizzard's view, its customers, not MDY, were the direct infringers.

Blizzard alleged that MDY was liable for contributory copyright infringement because MDY materially contributed to this direct infringement in RAM by Glider users. ${ }^{23}$ MDY allegedly did so by developing and selling Glider with the knowledge that Glider users would create infringing RAM copies. ${ }^{24}$ Blizzard also alleged that MDY was liable for vicarious copyright infringement because MDY had the ability to stop the Glider-caused infringing activity and derived a financial benefit from that activity. ${ }^{25}$

The district court's decision turned in part on whether Blizzard's end users were owners of their copies of the client software. The district court held that users of WoW were "licensees of the copies of the game client software" rather than owners of the copies and were not entitled to a $\int 117$ defense because of this. ${ }^{26}$ Without a $\ 117$ right to make essential-step copies, the district court found that end users needed a license to make RAM copies of the software while playing it. ${ }^{27}$ Since Glider users were violating the EULA and TOU by using a bot, the court, essentially adopting Blizzard's view, held that any use of WoW by a Glider user that created a RAM copy (i.e., essentially all such uses) was outside the scope of the EULA/TOU and hence was infringement. ${ }^{28}$ Having established then that Glider users were direct infringers, the court concluded without commentary that MDY was

21. Arguably the restriction violated is one on using unapproved third-party interfaces to the games. Furthermore, MDY repeatedly pointed out in its briefs that the agreements did not forbid bots when MDY began its business. MDY has argued that Blizzard should not be able to unilaterally put an end to MDY's business by changing its agreements with its end users. See Motion for Summary Judgment, supra note 19, at 41.

22. See id. at $5-7$.

23. Id. at 8-9.

24. See id.

25. Id. at 9 .

26. MDY Indus. LLC v. Blizzard Entm't, Inc., No. CV-06-2555-PHX-DGC, 2008 WL 2757357, at $* 9$ (D. Ariz. July 14, 2008). As discussed infra Section V.A.1, I believe the inherent ambiguity in "licensees of the copies" leads to confusion.

27. See id. at *8-9.

28. See id. at $* 8-10$. 
liable for contributory copyright infringement, presumably because MDY materially contributed to the supposed direct infringement by Glider users. ${ }^{29}$

While there are many details of the district court's decision that also deserve scrutiny, the chief problem with the result can now be made clear: if copyright owners can, through carefully worded EULAs, both retain title to copies of their copyrighted works and forbid the use of those copies in conjunction with third-party software on pain of license termination, then copyright owners can control those external markets with the stroke of a pen.

A hypothetical may make the situation clearer: Under the district court's rationale, Microsoft could add a term to its Word EULA forbidding the use of third-party software that integrates into Word. It would thereby make a secondary infringer out of Thomson Reuters, the makers of the Endnote bibliographic software that integrates into and interoperates with Word. ${ }^{30}$ Microsoft could do this out of spite, to extract fees from Thomson, or to favor its own stand-alone bibliographic software-were they to make anyor even for more benign reasons such as preventing the use of third-party software that might make Word more prone to crash. Microsoft Word may be the market-leading word processing software, but it is not anti-trust grounds that would make such a licensing technique objectionable. This competition via license would be wrong merely because the copyright owner was misusing its copyright in order to control independent interoperable software made by third parties. That is precisely what Blizzard has done here, and it constitutes copyright misuse. ${ }^{31}$

While the Ninth Circuit looked primarily to other grounds for reversing the district court's decision on secondary copyright liability in MDY Industries, ${ }^{32}$ the holding that purchasers of copies of WoW were not owners of those copies for purposes of $\int 117$ was flawed. A contrary holding on that issue alone would have prevented the harm just described.

29. See id. at $* 10$.

30. See ENDNOTE, http://www.endnote.com (last visited Sept. 17, 2010).

31. Lasercomb Am., Inc. v. Reynolds, 911 F.2d 970, 979 (4th Cir. 1990) ("The misuse arises from Lasercomb's attempt to use its copyright in a particular expression, the Interact software, to control competition in an area outside the copyright, i.e., the idea of computerassisted die manufacture, regardless of whether such conduct amounts to an antitrust violation.").

32. MDY Indus. LLC v. Blizzard Entm’t, Inc., 629 F.3d 928 (9th Cir. 2010). 


\section{The Distinction Between the Intangible Copyright AND the TANGIBLE COPY}

Part III, which reviews the various approaches taken by the courts to the question of copy ownership, criticizes the courts' equivocal uses of the words "license" and "software." Such equivocation is a chief reason many courts reach the wrong result on the question of copy ownership. When reading these court decisions, one must always ask, "license to what?"

Software distributors use the word "license" to describe a permanent transfer of a copy of a copyrighted work in which the transferor purportedly retains full title to and ownership of the transferred copy. ${ }^{33}$ No other type of transfer of a tangible good is comparable. ${ }^{34}$ A sale or gift involves the passing of title to the recipient. A rental, lease, or lending involves only a temporary transfer of rightful possession of the thing rented, leased, or loaned, with an expectation that the period of rightful possession will cease and the good transferred must be returned. ${ }^{35}$ But the software distributor's "license"

33. See infra Section V.A.1.

34. There is a notion of a "license" with respect to real property, but software distributors use the term with respect to chattel. See 53 C.J.S. Licenses \133 (2010). Section 133 states:

A real property license is simply the authority to enter the land of another and perform a specified act or series of acts without obtaining any permanent interest in the land. It is a permit or privilege to do what otherwise would be a trespass, a tort, or otherwise unlawful.

Id. A "bailment" is created when the owner of a chattel gives another person possession of the chattel without granting that person title to it. RESTATEMENT (THIRD) OF TRUSTS \ 5 cmt. $\mathrm{f}$ (2003). But a bailment also provides the bailor with the right to terminate the bailment at any time and to demand that the bailee deliver the property on demand. United States v. Alcaraz-Garcia, 79 F.3d 769, 775 (9th Cir. 1996). No software distributor has suggested that - without cause - it could simply demand return of consumer software at any time as it could if the relationship were truly one of bailment. See Sturm v. Boker, 150 U.S. 312, 32930 (1893). In Sturm v. Boker, the Court found:

The recognized distinction between bailment and sale is that, when the identical article is to be returned in the same or in some altered form, the contract is one of bailment, and the title to the property is not changed. On the other hand, when there is no obligation to return the specific article, and the receiver is at liberty to return another thing of value, he becomes a debtor to make the return, and the title to the property is

Id. changed. The transaction is a sale.

35. U.C.C. \2A-103(1)(j) (2003) (“' 'Lease' means a transfer of the right to possession and use of goods for a term in return for consideration ....”); BLACK'S LAW DICTIONARY 970 (9th ed. 2009) ("lease, $n$. . . 5. A contract by which the rightful possessor of personal property conveys the right to use that property in exchange for consideration.”); BLACK'S LAW DICTIONARY, supra, at 985 ("lend, $v b$. 1. To allow the temporary use of (something), sometimes in exchange for compensation, on condition that the thing or its equivalent be 
typically involves no such expectation of return. It is a wholly unprecedented form of transferring a tangible object-a fiction invented by software distributors. ${ }^{36}$

The choice to call this permanent transfer of a tangible good a "license" when that word already had an established usage ${ }^{37}$ has been the source of enormous confusion. No one disputes that copyright owners may license their exclusive rights under copyright. Furthermore, no one disputes that end users of software granted such copyright licenses are rightly called "licensees" when the word "license" is used to refer to the granting of permissions with respect to a copyright owner's exclusive rights found in $\$ 106$. But this Article does dispute that copyright owners may "license" tangible copies of copyrighted works. Individuals who have a right to perpetual possession of a copy of a copyrighted work should not be called "licensees" in this sense, where the word "license" is used to refer to a permanent transfer of a copy of a copyrighted work in which the transferor purportedly retains full title to and ownership of the transferred copy. There simply is no such thing in copyright law. One may license exclusive rights, not tangible goods.

returned."); BLACK'S LAW DICTIONARY, supra, at 1410 ("rent, n. 1. Consideration paid, usu. periodically, for the use or occupancy of property (esp. real property).”).

36. It is comparable to attempts to impose servitudes on chattel, but even in those cases the parties typically agreed that a sale and some form of ownership, even if burdened by the servitude, had transferred. See Zechariah Chafee, Jr., Equitable Servitudes on Chattels, 41 HARV. L. REV. 945 (1928); Molly Shaffer Van Houweling, The New Servitudes, 96 GEO. L.J. 885 (2008). The software distributors' "license" appears to be a scheme designed to avoid the concerns long expressed by courts and scholars about chattel servitudes.

37. See 53 C.J.S. Licenses $\$ 1$ (2010) ("A license is a right or permission granted by some competent authority to carry on a business or do an act which, without such license, would be illegal."). Black's Law Dictionary defines "license" as:

A permission, usu. revocable, to commit some act that would otherwise be unlawful; esp., an agreement (not amounting to a lease or profit à prendre) that it is lawful for the licensee to enter the licensor's land to do some act that would otherwise be illegal, such as hunting game.

BLACK'S LAW DICTIONARY, supra note 35, at 1002. 


\section{WHEN DOES TITLE TO A COPY PASS TO THE TRANSFEREE?}

Courts and commentators have adopted various approaches regarding when title to a copy of a copyrighted work passes to the transferee. This Part focuses on an exposition of the approaches, but critiques of these are reserved for the next Part. ${ }^{38}$

The various approaches used by courts are difficult to categorize precisely and often reflect a mixture of several distinct approaches. The approaches ${ }^{39}$ can be roughly distinguished as follows:

On one extreme is the Reservation of Title approach. Using this approach, courts focus almost exclusively on whether the copyright holder purports to reserve title in the copies through an accompanying agreement. For these courts, a mere recitation by the copyright holder of a few magic words is sufficient to make virtually all other features of the transaction irrelevant.

Slightly less extreme is the Agreement Controls approach. Under this approach, courts may look to a reservation of title first, or as one of several factors, in determining ownership of a copy. However, unlike under the Reservation of Title approach, which typically looks to a single clause in the agreement, courts employing an Agreement Controls approach examine the agreement more broadly to determine ownership of copies.

Some courts use the UCC Controls approach. Since the question confronting courts concerns the passing of title to a tangible good, these courts use the Uniform Commercial Code's ("U.C.C.") Passing of Title rules to resolve the question.

Other courts use the Economic Realities approach. These courts explicitly reject that mere words recited by the agreement govern the

38. This issue has received significant scholarly attention as well. In addition to those articles cited elsewhere herein, see, for example, Lothar Determann \& Aaron Xavier Fellmeth, Don't Judge a Sale by Its License: Software Transfers Under the First Sale Doctrine in the United States and the European Community, 36 U.S.F. L. REV. 1 (2001); Nancy S. Kim, The Software Licensing Dilemma, 2008 BYU L. REV. 1103; Joseph P. Liu, Owning Digital Copies: Copyright Law and the Incidents of Copy Ownership, 42 WM. \& MARY L. REV. 1245 (2001); Christian H. Nadan, Software Licensing in the 21st Century: Are Software "Licenses" Really Sales, and How Will the Software Industry Respond?, 32 AIPLA Q.J. 555 (2004); R. Anthony Reese, The First Sale Doctrine in the Era of Digital Networks, 44 B.C. L. REV. 577 (2003); David A. Rice, Digital Information as Property and Product: U.C.C. Article 2B, 22 U. DAYTON L. REV. 621 (1997); David A. Rice, Licensing the Use of Computer Program Copies and the Copyright Act First Sale Doctrine, 30 JURIMETRICS J. 157 (1990); John A. Rothchild, The Incredible Shrinking First-Sale Rule: Are Software Resale Limits Lawful?, 57 RUTGERS L. REV. 1 (2004).

39. The names of the different approaches are my own inventions. 
determination of ownership of a copy. Instead, they look to the substance of the transaction and consider its "economic realities." They consider factors such as the terms of the agreement not related to copyright permissions and facts about the transaction or its consequences not discussed in the agreement at all.

Finally, two district courts have used the Perpetual Possession approach, a more theoretically satisfying application of the reasoning underlying the Economic Realities approach. Under this approach, the right to perpetual possession of a copy is determinative. These courts clarified the law not by ignoring precedent, but by following it more faithfully and by understanding what was important in earlier cases addressing this issue. The Perpetual Possession approach satisfies the three essential requirements for a proper approach to determining copy ownership: logical consistency, respect of precedent, and respect for congressional choices.

\section{A. The Reservation of Title Approach}

"Far too often, courts merely accept plaintiff's description of the transaction as a license." William Patry.

Courts that employ the Reservation of Title approach make it easy for the copyright holder to prevent transfer of ownership of a copy. These courts have looked to the agreement between the parties for guidance, but they have been satisfied with the slimmest of facts favoring the copyright holder. In some cases, it has been enough for copyright holders to simply make a representation to the court that they "license their software" and do not "sell" it. This extreme sub-variety of the Reservation of Title approach can be dubbed the "Magic Words" approach, because for these courts the magic words "we license not sell" ends the inquiry. Other courts following the Reservation of Title approach delve slightly deeper and look for specific language in the agreement reserving title in the copies to the copyright holder. If such language is found, these courts place all or almost all of the weight on this factor and find no transfer of title.

1. The "Magic Words" Cases: MAI Systems Corp. v. Peak Computer, Inc. and Microsoft Corp. v. Harmony Computers \& Electronics, Inc.

A cursory, unsupported footnote, consisting of a single declarative sentence, in the Ninth Circuit's MAI Systems Corp. v. Peak Computer opinion has done more damage to the appropriate development of the law with

40. 4 William F. Patry, Patry On COPYRight \13:25 (2010). 
respect to transfer of title of copies than perhaps anything else. The court's entire analysis of the issue of copy ownership occurred in the following sentence: "Since MAI licensed its software, the Peak customers do not qualify as 'owners' of the software and are not eligible for protection under $\int 117 . "{ }^{41}$ The court's conclusory pronouncement on this topic has been widely criticized by both leading commentators ${ }^{42}$ and the Court of Appeals for the Federal Circuit, ${ }^{43}$ a fact recognized by the Ninth Circuit itself in a subsequent opinion. ${ }^{44}$ The main fault articulated is that the $M A I$ court's statement fails to pay heed to 17 U.S.C. $\int 202 .{ }^{45}$ The $M A I$ court conflated the intangible copyright with the tangible copy, and it thus failed to recognize that a licensee of one of the rights of copyright might also be an owner of a particular copy. ${ }^{46}$

Notably, the Ninth Circuit cited to no statute or precedent for this supposed dichotomy between licensees and owners of a copy. Nevertheless, the damage has been extensive because this opinion represented one of the earliest instances of a circuit court addressing the question in the software context, ${ }^{47}$ and thus it has been cited and followed by subsequent courts. ${ }^{48}$

41. See MAI Sys. Corp. v. Peak Computer, Inc., 991 F.2d 511, 518 n.5 (9th Cir. 1993). The court rendered this decision without the benefit of oral argument. Id. at 511.

42. See, e.g., 2 Melville B. Nimmer \& David Nimmer, Nimmer ON Copyright $\int 8.08[\mathrm{~B}][1][\mathrm{c}](1997)$. 1999).

43. See DSC Commc'ns Corp. v. Pulse Commc'ns, Inc., 170 F.3d 1354, 1360 (Fed. Cir.

44. Wall Data Inc. v. L.A. Cnty. Sheriff's Dep't, 447 F.3d 769, 785 n.9 (9th Cir. 2006).

45. 17 U.S.C. $\$ 202$ (2006) ("Ownership of a copyright, or of any of the exclusive rights under a copyright, is distinct from ownership of any material object in which the work is embodied.").

46. See DSC Commins, 170 F.3d at 1360; NIMMER, supra note 42, at 8.08[B][1][c]. Although some might group another MAI case, Advanced Computer Services of Michigan, Inc. $v$. MAI Systems Corp., 845 F. Supp. 356, 367 (E.D. Va. 1994), with the one discussed in the text of this Section, I follow Nimmer in concluding that it is so wide off the mark that it does not even cite the most crucial phrase- "of a copy" - in $\ 117$, and so I do not discuss that case further.

47. The issue was previously addressed in the software context by a circuit court in S.O.S., Inc. v. Payday, Inc., 886 F.2d 1081, 1088 (9th Cir. 1989), discussed infra Section III.A.2.

48. See, e.g., Wall Data, 447 F.3d at 784-85 ("[U]nder $M A I$, if a software developer retains ownership of every copy of software, and merely licenses the use of those copies, \117 does not apply."). There is another case, Triad Systems Corp. v. Southeastern Express Co., 64 F.3d 1330 (9th Cir. 1995), which I do not discuss at length because the court merely (and erroneously) assumed that there is an insuperable distinction between licensees and owners of copies. Id. at 1333 ("In 1986, however, Triad began licensing rather than selling its software ...."). It is thus not accurate to say that Triad "followed" $M A I$ with respect to the issue of copy ownership, although the courts committed similar errors. 
In the year after the $M A I$ decision, the court in Microsoft Corp. v. Harmony Computers \& Electronics, Inc. ${ }^{49}$ furthered the unfortunate trend of short statements that fail to carefully distinguish between copyrights and copies. The Harmony court stated, "[e]ntering a license agreement is not a 'sale' for purposes of the first sale doctrine." ${ }^{50}$ However, the court failed to recognize that selling a copy and entering into a license agreement are not mutually exclusive: whether there is a sale for purposes of the first sale doctrine involves ownership of a particular copy, something that is completely consistent with entering a license agreement.

The court's statement is particularly unfortunate because it appears that the defendant was selling counterfeit copies ${ }^{51}$ and, since such copies were not "lawfully made," 52 the first sale doctrine would not have applied for that more fundamental reason. ${ }^{53}$ Still, evidence of the counterfeiting might not have changed the court's grounds for rejecting the first sale defense, as the court implied that it would have been satisfied with mere declarations from Microsoft that it "license[d] and d[id] not sell" its software. ${ }^{54}$

49. 846 F. Supp. 208 (E.D.N.Y. 1994).

50. Id. at 213 (E.D.N.Y. 1994); see also Microsoft Corp. v. ATS Computers, No. 931273, 1993 WL 13580935, at *5-6 (S.D. Cal. Oct. 29, 1993) (making some statements suggestive of a "magic words" approach, but ultimately deciding the issue based on the defendant's failure to offer any evidence that a sale occurred).

51. Harmony, 846 F. Supp. at 212.

52. 17 U.S.C. $\int 109$ (a) (2006).

53. The court was ruling on a preliminary injunction within the first weeks of the case and had not yet held an evidentiary hearing to make a finding on the genuineness of the products sold by defendants. Harmony, 846 F. Supp. at 212. Microsoft made an ex parte application for seizure of the allegedly counterfeit product on January 12, 1994, and the court's ruling here was issued February 7, 1994, just twenty-six days later. Id. at 209, 212.

54. Id. at 213. The court stated:

Plaintiff's counsel declares that Microsoft only licenses and does not sell its Products. Entering a license agreement is not a "sale" for purposes of the first sale doctrine. Moreover, the only chain of distribution that Microsoft authorizes is one in which all possessors of Microsoft Products have only a license to use, rather than actual ownership of the Products.

Id. (citing ISC-Bunker Ramo Corp. v. Altech, Inc., 765 F. Supp. 1310, 1311 (N.D. Ill. 1990)). The court also looked to the fact that Microsoft " "established a course of conduct... consistent with an intention to retain all the rights associated with the grant of copyright' of the Microsoft Products." Id. (quoting Am. Int'l Pictures, Inc. v. Foreman, 576 F.2d 661, 665 (5th Cir. 1978)). By focusing here on the rights of copyright, the court conflated the intangible copyright with the tangible copy. Also, the case cited to, ISC-Bunker, contained no analysis of the copy ownership issue and simply concluded, "given the substantial evidence that ISC only licensed and did not sell its copyrighted software, the first sale doctrine has no application to Altech as a matter of law." ISC-Bunker, 765 F. Supp. at 1331. Exactly what the "substantial evidence" was, is unclear from that court's discussion. Another case that simply followed Harmony without analysis is Microsoft Corp. v. Software Wholesale Club, Inc., 129 F. 


\section{Wall Data Inc. v. L.A. County Sheriff's Department and S.O.S.} Inc. v. Payday, Inc.

Two additional Ninth Circuit opinions appear to have adopted the Reservation of Title approach in an uncritical manner: Wall Data Inc. v. L.A. County Sheriff's Department ${ }^{55}$ and S.O.S. Inc. v. Payday, Inc. ${ }^{56}$ In a passage where the Wall Data court had been discussing $M A I$, the court wrote, "[g]enerally, if the copyright owner makes it clear that she or he is granting only a license to the copy of software and imposes significant restrictions on the purchaser's ability to redistribute or transfer that copy, the purchaser is considered a licensee, not an owner, of the software." 57 The Wall Data court cited to no authority beyond $M A I$, which itself cited to no statute or precedent in support of its conclusory statement addressing ownership of copies. ${ }^{58}$ Thus, the approach just articulated has no obvious precedential basis.

However, W all Data lacks vitality as a copy ownership case because the court went out of its way to indicate that "a more fundamental reason" for its decision was the fact that the Sheriffs Department's actions would not constitute an "essential step" as required by $\int 117 .{ }^{59}$ Thus, whether the Department owned its copies or not was not the fundamental basis of the

Supp. 2d 995, 1002 (S.D. Tex. 2000) ("If the copyright owner licenses, rather than sells, the copyrighted work, the first-sale doctrine may not apply.") (citing Harmony, 846 F. Supp. at 212-14). Another case of interest is Davidson \& Assocs. v. Internet Gateway, 334 F. Supp. 2d 1164, 1177 (E.D. Mo. 2004), aff'd, 422 F.3d 630 (8th Cir. 2005). In Davidson, the court found:

[T] he EULAs and TOU are enforceable under the UCC. First, the defendants did not purchase the Blizzard software, rather they purchased a license for the software. A sale consists in the passing of title from the seller to the buyer. When defendants purchased the games, they bought a license to use the software, but did not buy the software .... The EULAs and TOU in this case explicitly state that title and ownership of the games and Battle.net remain with Blizzard. Defendants do not produce sufficient evidence demonstrating that title and ownership of the games passed to them.

Id. at 1177-78 (citations omitted). This court also conflated the intangible copyright with the tangible copy, equivocating on the use of the word "software." Reserving title to "the games" or to "Battle.net" is not the same thing as reserving title to the tangible medium in which the game is embodied.

55. 447 F.3d 769 (9th Cir. 2006).

56. 886 F.2d 1081 (9th Cir. 1989).

57. Wall Data, 447 F.3d at 785. That the court qualified this statement with "generally" suggests one of many reasons not to take the Wall Data court as stating a universallyapplicable test for determining copy ownership.

58. Wall Data does cite to Adobe Systems, Inc. v. One Stop Micro, Inc., 84 F. Supp. 2d 1086 (N.D. Cal. 2000), in a footnote in order to quote some of the declarations of members of the software industry, but this is neither statute nor controlling precedent. Wall Data, $447 \mathrm{~F} .3 \mathrm{~d}$ at 787 n.9.

59. 17 U.S.C. $\int 117$ (2006). 
Court's decision. ${ }^{60}$ For that reason, Wall Data should not be treated as a controlling precedent on the issue of under what circumstances title to a copy passes to a transferee, and it should not guide district courts squarely facing that question. ${ }^{61}$

Perhaps more importantly, as is explained later in this Section, the controlling precedent in the Ninth Circuit on this issue is found in an opinion never cited in Wall Data. ${ }^{62}$ Many Circuits have adopted a "rule of orderliness" that when two panel opinions are like "ships passing in the night" and a subsequent panel reaches a contrary result without mentioning the earlier case, "the later opinion is a nullity; any other rule would invite judicial chaos." "T3 Therefore, for failure even to consider, much less follow, controlling precedent, $W$ all Data should be treated as a nullity with respect to determining the circumstances in which title to a copy passes to a transferee.

In S.O.S. Inc. v. Payday, Inc., the Ninth Circuit appeared to be satisfied with any statement that might reserve title in the copy. In this case, the transferee merely rented the computer on which the disputed copy of software resided. The Ninth Circuit wrote,

60. See Wall Data, 447 F.3d at 785 n.9.

61. The result might be different if the two rationales in Wall Data were "alternate" holdings both equally supporting its decision, but the court itself chose to describe the "essential step" holding as "more fundamental." Id. The limitation of $\int 117(\mathrm{a})(1)$ applies to (i) owners of a copy that make another copy, (ii) created as an essential step, (iii) that is used in no other manner. Since the statute treats all these requirements equally, the court should be interpreted to have rested its ruling solely on the "essential step" issue because there is nothing inherently or statutorily "more fundamental" about that requirement. Thus, for the court to use such language should be taken to indicate its determination of the basis of its ruling. Further, as already indicated, on the "owner" issue the Wall Data court merely cited to $M A I$, which provided a single footnote which cited to nothing, and so deserves less deference than the earlier DAK Industries or United States v. Wise, 550 F.2d 1180 (9th Cir. 1997), decisions which provided far more guidance on how to make the ownership determination. It is unfortunate that the Wall Data court failed to cite or discuss those two cases, as then it could have helped to clarify this troublesome area of law.

62. See Wise, 550 F.2d 1180, discussed infra Section III.D.1.

63. Grabowski v. Jackson Cnty. Pub. Defenders Office, 47 F.3d 1386, 1400 n.4 (5th Cir. 1995) (Smith, J., concurring in part and dissenting in part). The full quote follows:

[O] ur rule of orderliness comes into play when two panels become "ships passing in the night." A subsequent panel may be unaware of an earlier holding and, consequently, may reach a contrary result. No interpretation is involved, as the later panel makes no mention of the earlier case. In such an instance, we can easily say that the later opinion is a nullity; any other rule would invite judicial chaos.

Id. (emphasis in original); see also Recursion Software, Inc. v. Interactive Intelligence, Inc., 425 F. Supp. 2d 756, 776-77 (N.D. Tex. 2006) (discussing the Fifth Circuit's rule of orderliness). 
[t] he literal language of the parties' contract provides that S.O.S. retains "all rights of ownership." (Emphasis added.) This language plainly encompasses not only copyright ownership, but also ownership of any copies of the software. Payday has not demonstrated that it acquired any more than the right to possess a copy of the software for the purpose of producing "product" for its customers. ${ }^{64}$

However, the court here also repeatedly noted that Payday was to lease the computers on which the software at issue ran, and that these computers would even reside in a third-party accountant's office, and thus the parties initially may not have even contemplated that Payday would ever possess a copy of the software. ${ }^{65}$ Thus, while the language used by the court here appears to be a strong statement of a Reservation of Title approach, the rationale behind the court's decision may be more nuanced. When evaluating the contract as a whole, the court saw a leasing arrangement that applied not only to the computer hardware, but to the individual copies of the software as well.

The approach advocated in this Article does not seek to disturb the fact that a true lease should be treated as a lease that does not give rise to $\int 109$ or \117 rights. A true lease is found in the S.O.S. case, and while the court reached the correct result, its rationale and explanation make this case less useful in guiding courts trying to determine whether an agreement denominated a "license" actually provides for the sale of copies. ${ }^{66}$ The court's suggestion here that merely stating that one reserves "all rights of ownership" without even specifying whether one intends to reserve one's copyrights or one's rights in the tangible thing in which one's copyrighted work might be embodied, borders on a "magic words" sort of approach. But the court's explanation that Payday was engaged in the "rental of computer time" suggests that the court concluded that the transaction was really a rental or lease. $^{67}$

In summary, the Reservation of Title approach largely looks to the agreement accompanying the copy, focusing especially on whether the copyright holder makes any claim to reserve title in the copies delivered to the transferee. Too often courts adopting this approach rely solely on the word "license" as if the mere incantation of that word puts an end to the inquiry. Other courts rightly dig deeper.

64. S.O.S. Inc. v. Payday, Inc., 886 F.2d 1081, 1088 (9th Cir. 1989).

65. See id. at 1088 n.9.

66. The S.O.S. court's failure to cite Wise also weakened its discussion of the sorts of factors one should consider when determining title to a copy.

67. See S.O.S., 886 F.2d at 1088 n.9. 
B. The AgreEMENT CONTROLS APPROACH

"The terms of the contract control." Raymond T. Nimmer (2006). ${ }^{68}$

Some courts and commentators have explicitly or impliedly adopted a view that the agreement that accompanies a copy of a copyrighted work completely controls whether title to the tangible thing passes to the recipient or remains with the copyright holder. On this view, one looks almost exclusively to the four corners of the agreement to determine if the possessor of a copy of a copyrighted work is also the owner of that copy.

For example, Raymond T. Nimmer has written, "since Section 117 does not delineate when a person becomes an owner of a copy of a computer program, whether ownership is transferred will be determined in light of and controlled by the agreement of the parties. The terms of the contract control." ${ }^{69}$ He buttressed this view with the further proviso that where an agreement is silent on copy ownership, "courts should look to the context of the transaction, including any established industry practice of licensing rather than selling copies." 70

68. Raymond T. Nimmer, The LaW of Computer TeCHnOlogy \1:115 (2006).

69. Id.

70. Id. Raymond T. Nimmer's view has apparently developed over the years, as several courts quote earlier versions of his text for what appear to be different views. Nimmer has written:

Ownership of a copy should be determined based on the actual character, rather than the label, of the transaction by which the user obtained possession. Merely labeling a transaction as a lease or license does not control. If a transaction involves a single payment giving the buyer an unlimited period in which it has a right to possession, the transaction is a sale. In this situation, the buyer owns the copy regardless of the label the parties use for the contract. Course of dealing and trade usage may be relevant, since they establish the expectations and intent of the parties. The pertinent issue is whether, as in a lease, the user may be required to return the copy to the vendor after the expiration of a particular period. If not, the transaction conveyed not only possession, but also transferred ownership of the copy.

Applied Info. Mgmt. v. Icart, 976 F. Supp. 149, 154 (E.D.N.Y. 1997) (citing RAYMOND Nimmer, The LAW OF COMPUTER TeChNology \1.18[1], at 1-103 (1992)). A similar sentiment is echoed in the DSC Commc'ns opinion. DSC Commc'ns Corp. v. Pulse Commc'ns, Inc., 170 F.3d 1354, 1362 (Fed. Cir. 1999) (“One commentator has argued that when a copy of a software program is transferred for a single payment and for an unlimited term, the transferee should be considered an 'owner' of the copy of the software program regardless of other restrictions on his use of the software." (citing RAYMOND T. NIMMER, The LAW OF Computer TeChNOlogy \$1.24[1], at 1-143-44 (3d ed. 1997))). Such language no longer appears in the 2006 or 2009 editions, and as a "looseleaf" treatise whose pages are updated and often discarded, it is difficult to trace the development of Prof. 
When courts adopt this view, it often takes the form of evaluating the terms of the agreement to determine what restrictions are placed on the copyright permissions granted to the recipient. Part V explains why such an approach is misguided. First, I review some examples of this approach in particular cases.

1. DSC Communications Corp. v. Pulse Communications, Inc.

In DSC Communications Corp. v. Pulse Communications, Inc., ${ }^{71}$ the Federal Circuit wrote,

[p]lainly, a party who purchases copies of software from the copyright owner can hold a license under a copyright while still being an "owner" of a copy of the copyrighted software for purposes of section 117 . We therefore do not adopt the Ninth Circuit's characterization of all licensees as nonowners. Nonetheless, the $M A I$ case is instructive, because the agreement between MAI and Peak, like the agreements at issue in this case, imposed more severe restrictions on Peak's rights with respect to the software than would be imposed on a party who owned copies of software subject only to the rights of the copyright holder under the Copyright Act. And for that reason, it was proper to hold that Peak was not an "owner" of copies of the copyrighted software for purposes of section $117 .^{72}$

Raymond T. Nimmer's evolving view. However, the 2006 and 2009 editions contain numerous statements that suggest he now advocates a Reservation of Title approach. See NIMMER, supra note $68, \mathbb{S} 1: 115$, at 1-302 (" $\mathrm{I}$ f the terms of a license provide that ownership of the copy and the copyright remain in the copyright owner, the provisions preclude transfer of title to the copy of the licensee."); RAYMOND T. NIMMER, THE LAW OF Computer Technology \1.110, at 1-268-69 (4th ed. 2009). Prof. Raymond T. Nimmer was retained as Autodesk's expert in the Vernor case, and the district court there also noted that his views on this issue appear to have changed over time. See Vernor v. Autodesk, Inc., No. C07-1189RAJ, 2009 WL 3187613, at*1-2, 9-11 (W.D. Wash. Sept. 30, 2009) ("While Autodesk asks the court to defer to Mr. Nimmer's views, it does not acknowledge that those views have proven malleable.”).

71. 170 F.3d 1354.

72. Id. at 1359 (applying Fourth Circuit law, but finding none on point); see also Adobe Sys. v. One Stop Micro, Inc., 84 F. Supp. 2d 1086, 1091 (N.D. Cal. 2000) ("These numerous restrictions imposed by Adobe indicate a license rather than a sale because they undeniably interfere with the reseller's ability to further distribute the software."). In One Stop Micro, the court held:

[B] ased upon the undisputed evidence submitted by Adobe regarding the intent of the parties in entering into the agreement, trade usage, the unique nature of distributing software, as well as the express restrictive language of the contract, the OCRA is a licensing agreement. Thus, contrary to One Stop's assertions, the OCRA does not represent a first sale between the reseller and Adobe.

84 F. Supp. 2d at 1092; see also Adobe Sys. v. Stargate Software, Inc., 216 F. Supp. 2d 1051, 1055 (N.D. Cal. 2002) ("The determination of ownership in turn is based primarily on an 
Here, the Federal Circuit did not conflate the intangible copyright with the tangible copy and appears to have been focused on the correct issue. The court misstepped, however, when it allowed consideration of a restriction on a permission related to a right of copyright to guide its determination of ownership of a copy. The court wrote,

[T] he DSC-Ameritech agreement provides that Ameritech shall "not provide, disclose or make the Software or any portions or aspects thereof available to any person except its employees on a 'need to know' basis without the prior written consent of [DSC] ...." Such a restriction is plainly at odds with the section 109 right to transfer owned copies of software to third parties. ${ }^{73}$

The Federal Circuit noted that the agreement purported to prohibit the end users of the software "from using the software on hardware other than that provided by DSC." "74 The Supreme Court ${ }^{75}$ and other courts, however, have expressed concern about the restraint of trade and efforts to extend the copyright (or patent) monopoly beyond the covered work to unrelated goods. ${ }^{76}$ It is perplexing that the Federal Circuit failed to consider that problem here, especially because the court was bound to apply Fourth Circuit law, where a leading copyright misuse case, Lasercomb, was decided. ${ }^{77}$ Had the

examination of the OCRA, the agreement between Adobe and its distributors."); Icart, 976 F. Supp. at 155 (finding that where no terms defined the transfer of a copy and where payment was divided into three different payment periods, ownership of a copy was an issue of fact precluding summary judgment). Note that Raymond T. Nimmer was Adobe's expert in One Stop Micro. 84 F. Supp. 2d at 1091. These cases are discussed herein as exemplars of the Reservation of Title approach, but these statements show that the approaches are more of a continuum than distinct categories, and that in particular, the Reservation of Title approach could be thought of as simply a more formalistic variety of the Agreement Controls approach in which the reservation of title clause in the agreement is given dispositive weight.

73. DSC Commc'ns, 170 F.3d at 1361. Looking to restrictions on subsequent distribution to determine copy ownership is misguided in several ways. See infra Part V.

74. DSC Commins, 170 F.3d at 1361.

75. See Sony Corp. of Am. v. Universal City Studios, Inc., 464 U.S. 417, 441 (1984) (finding it extraordinary to suggest that the Copyright Act conferred upon all copyright owners collectively, the exclusive right to distribute VTRs simply because they may be used to infringe copyrights, and finding that to construe copyright law as Universal urged would have enlarged the scope of Universal's statutory monopolies to encompass control over an article of commerce that was not the subject of copyright protection); Motion Picture Patents Co. v. Universal Film Mfg. Co., 243 U.S. 502 (1917); Bauer \& Cie v. O’Donnell, 229 U.S. 1 (1913); Bobbs-Merrill Co. v. Straus, 210 U.S. 339 (1908).

76. See Alcatel USA, Inc. v. DGI Techs., Inc., 166 F.3d 772 (5th Cir. 1999) (affirming the district court's finding that DSC used its copyrights to indirectly gain commercial control over its non-copyrighted microprocessor cards, which constituted misuse).

77. On the non-patent issues, such as the copyright and state law issues, the Federal Circuit follows the law of the circuit from which the appeal is taken; in this case, the Fourth Circuit. DSC Commc'ns, 170 F.3d at 1359 (citing Glaxo, Inc. v. Novopharm, Ltd., 110 F.3d 
court been confronted by a Microsoft Windows license agreement that purported to require that the software only be used on computers provided by Microsoft, would the court have enforced the agreement and prevented the entire computer industry from functioning as we know it? ${ }^{78}$ If not, and market power is the distinguishing factor, then the court should have at least noted that such a restriction could only be enforced where not anticompetitive.

2. Novell, Inc. v. CPU Distributing, Inc. and Novell, Inc. v. Unicom Sales, Inc.

Novell, Inc. v. CPU Distributing, Inc. ${ }^{79}$ provides another example of the Agreement Controls approach. This case involved the resale of Novell's NetWare software by the defendant, who had acquired the software from original equipment manufacturers ("OEMs"). Novell alleged that the OEMs were mere licensed distributors rather than owners of the copies. The court wrote,

To determine whether the transfer of copies of Novell software from Novell to its OEMs is a sale, the Court must construe the OEM Agreement between Novell and each of the OEMs. The OEM Agreement provides that it will be "construed in accordance with the laws of the State of Utah . ..."80

Here the opinion provides an example of one of the deficiencies of the Agreement Controls approach. Such an approach appears to require resort to the varying laws of the states. In this case, the court looked to Utah law, but since the choice of law depends on the jurisdiction specified in the agreement, in other cases courts have looked to the canons of contract construction from other states. ${ }^{81}$

In this case, though, the particular choice of law did not appear to determine the result. Once the court determined to look to the agreement, the court found "unambiguous sales language" throughout the agreement,

1562, 1572 (Fed. Cir. 1997), and Atari, Inc. v. JS \& A Group, Inc., 747 F.2d 1422, 1439-40 (Fed. Cir. 1984) (en banc)); see also Lasercomb Am., Inc. v. Reynolds, 911 F.2d 970 (4th Cir. 1990).

78. As of this writing one is still free to purchase computer hardware capable of running Microsoft operating systems from Hewlett-Packard, Dell, Acer, Lenovo, Toshiba, Apple, and from numerous components manufacturers.

79. No. H-97-2326, 2000 U.S. Dist. LEXIS 9975 (S.D. Tex. May 4, 2000).

80. Id. at $* 11$.

81. Applied Info. Mgmt., Inc. v. Icart, 976 F. Supp. 149 (E.D.N.Y. 1997) (applying New York law); Novell, Inc. v. Network Trade Ctr., Inc., 25 F. Supp. 2d 1218, 1229-31 (D. Utah 1997) (applying the U.C.C.). 
citing nearly two dozen examples. ${ }^{82}$ Furthermore, there are two features of the court's reasoning that are more characteristic of the Economic Realities approach. ${ }^{83}$ First, the court seemed swayed by the fact that all risk of loss passed to defendants upon delivery of the copies. ${ }^{84}$ Second, nothing in the contract suggested that Novell was providing only temporary possession of the copies to defendants and expected the copies returned to Novell if unsold. However, given the court's overall focus on allowing the terms of the agreement to control, the opinion is better categorized with the Agreement Controls cases.

This opinion wisely avoided looking to restrictions on the rights of copyright to determine copy ownership. For example, the court considered the term of the agreement that provided that "OEM agrees not to provide Novell Products or any part or copies thereof to any third party without the prior written consent of Novell." 85 Other courts have viewed this sort of term restricting transfers as nearly decisive. ${ }^{86}$ Those courts have accordingly found that the transferees are not owners of the copies. ${ }^{87}$ But this court recognized the lesson of Supreme Court precedent and wrote, "[a]s was true in the Bobbs-Merrill case, this provision may contractually obligate the OEM not to transfer the copies except under the circumstances set forth in the OEM Agreement, but it does not preclude the application of the "first sale doctrine' as codified in $\$ 109$ (a)." 88

In Novell, Inc. v. Unicom Sales, Inc., ${ }^{89}$ the court applied the Agreement Controls approach even though it gave the impression it was looking at something more. The court wrote, "[i]n determining whether a transaction is a sale or a license, the Court reviews the substance of the transaction, rather than simply relying on the plaintiff's characterization of the transaction."90

82. See CPU Distrib., 2000 U.S. Dist. LEXIS 9975, at*13-17.

83. See infra Section III.D.

84. CPU Distrib., 2000 U.S. Dist. LEXIS 9975, at*16.

85. Id. at $* 17$ n. 7 .

86. E.g., MDY Indus. LLC v. Blizzard Entm't, Inc., No. CV-06-2555-PHX-DGC, 2008 WL 2757357, at *7-10 (D. Ariz. July 14, 2008).

87. E.g., id.

88. CPU Distrib., 2000 U.S. Dist. LEXIS 9975, at*17 n.7; see also Applied Info. Mgmt., Inc. v. Icart, 976 F. Supp. 149 (E.D.N.Y. 1997). The Icart court was also careful not to fall into some of the over-simplifications and logical errors of earlier decisions, and largely relied on the agreement in an effort to determine copy ownership. Icart, 976 F. Supp. at 149. But ultimately the court decided that there was a genuine issue of material fact as to whether the copy was owned and this precluded summary judgment. Id.

89. No. 03-2785, 2004 U.S. Dist. LEXIS 16861 (N.D. Cal. Aug. 17, 2004).

90. Id. at *28-29 (citing United States v. Wise, 550 F.2d 1180, 1190 (9th Cir. 1977)). 
Unicom Sales involved Novell software acquired under two different agreements. The defendants acquired some copies from Frederick County Public Schools ("FCPS"), who in turn had received the software from Novell under an agreement titled the "School License Agreement" ("SLA"). In examining the substance of that initial transaction, the court wrote that the license agreement

granted FCPS a license to copy the software for use only by its students and employees. The license was for a specific term of one year, and required payment of an annual license fee. When the SLA expired, FCPS was required to return the software to Novell. All of these terms are consistent with a license, rather than a sale. ${ }^{91}$

The court thus held that the first sale doctrine did not apply to defendants' distribution of such software. ${ }^{92}$ The Unicom Sales court focused on the terms of the agreement that restricted use to students and employees, charged an annual fee for the software, and required that the users return the software at the end of the term. This focus on contractual terms reflects the court's use of the Agreement Controls approach. ${ }^{93}$

The defendants had also acquired Novell software from parties who were termed "Qualified Educational Institutions" under Novell's Direct Education Order program ("DEO program"). ${ }^{94}$ Unlike the SLA software which involved FCPS itself signing an agreement with Novell, the Qualified Educational Institutions were not required to enter into a separate written license agreement, although a printed "software license" was included in the box in which the software was packaged. ${ }^{95}$

91. Id. at $* 30$.

92. Id. at $* 31$.

93. To the extent the court here looked at the one-year term, the annual license fee, and the requirement of return as part of a true rental or leasing arrangement, the Perpetual Possession approach, described infra Section III.E, would also have no quarrel with such considerations and would reach the same result. See Stuart Weitzman, LLC v. Microcomputer Res., Inc., 510 F. Supp. 2d 1098 (S.D. Fla. 2007), vacated, 542 F.3d 859 (11th Cir. 2008) (dismissing for lack of subject matter jurisdiction). This case represents another instance where the court appeared willing to look to the agreement, specifically at the restrictions on Stuart Weitzman's permissions with respect to rights of copyright, in order to determine title to the copies in Stuart Weitzman's possession. Id. However, the court ultimately applied factors consistent with the perpetual possession approach. Id. at 1107-09. In Unicom Sales, there was no signed agreement between the parties, and so the court turned instead to the factors identified in Krause v. Titleserv, Inc., 402 F.3d 119 (2d Cir. 2005), discussed infra Section III.D.3.

94. Unicom Sales, 2004 U.S. Dist. LEXIS 16861, at *6, *12 n.3.

95. Id. at $* 31$. 
At this point in the opinion the court displayed its narrower focus on the agreement more clearly: "the Court will proceed to examine the terms of Novell's Software License to determine whether it describes a sale or a license."96

The court then considered the following:

The agreement grants the right to use the software, for an unlimited period of time, but only within the customer's organization. If the customer breaches any of the terms, the license is automatically terminated, and the customer must either destroy the software or return it to Novell. The agreement expressly states that any rights not expressly granted are reserved to Novell. ${ }^{97}$

The court notes that SoftMan had found the perpetual possession factor to be key, but attempted to distinguish SoftMan by emphasizing that "[h]ere, although the Software License is not for a specific time period, it expressly requires return or destruction of the software if the license is terminated." 98 The court concluded that " $[\mathrm{t}]$ he limited rights in the software, as set forth in the Software License, describe a license in the software, rather than a sale."

This analysis of the DEO software agreement applies an Agreement Controls approach, emphasizing the term of the agreement that required return in event of breach.

\section{MDY Industries LLC v. Blizzard Entertainment, Inc.}

In the previously mentioned case of MDY Industries, some users of Blizzard's World of Warcraft multi-player online game used a bot program developed by MDY Industries to automate certain aspects of the game play. ${ }^{100}$ The district court addressed whether a purchaser of Blizzard's World of Warcraft ("WoW") software was an "owner" of his copy. ${ }^{101}$

The court wrote that "Wall Data provides a two-part test" to determine copy ownership, which the court applied to determine that purchasers of WoW were not owners of their copies of the software. ${ }^{102}$ The Wall Data

96. Id. at $* 35$ (emphasis added). The court later reiterated the need to look to substance, but did so only in order to dismiss the label on the agreement and not in order to focus on the realities of the transaction beyond the agreement's terms. Id. at *37.

97. $I d$. at $* 35$.

98. Id. at $* 36$ n.10.

99. Id. at *35. Setting up a dichotomy between "a license in the software" and "a sale" comes dangerously close to the logical errors that will be discussed infra Section V.A.

100. MDY Indus. LLC v. Blizzard Entm't, Inc., No. CV-06-2555-PHX-DGC, 2008 WL 2757357, at *8 (D. Ariz. July 14, 2008). For a full summary of the facts, see supra Section II.B. The case is also analyzed infra Part IV.

101. Id.

102. Id. 
court did not explicitly call its approach a "test" and even qualified its approach with the word "generally." 103 Nevertheless, the MDY Industries court looked at the following factors in deciding that purchasers of WoW did not own their copies of the software: First, the EULA accompanying the software expressly stated that "[a]ll title, ownership rights, and intellectual property rights in and to the Game and all copies thereof ... are owned or licensed by Blizzard." 104

Second, the MDY Industries court looked to restrictions on the transfer and use of the software. According to the EULA,

The user may transfer his "rights and obligations" under the EULA only by transferring the original media containing the game client software along with all original packaging and all manuals or other documentation distributed with the software; the user must delete all copies and installations of the software from his computer; and the recipient of the software must agree to the terms of the EULA. ${ }^{105}$

Third, the court noted that the TOU placed additional restrictions on the use of the software, restrictions that it felt were at least as severe as the restrictions in Wall Data. ${ }^{106}$

The Court concluded, therefore, that users of WoW were "licensees of the copies of the game client software" and were not entitled to the $\int 117$ defense because of this. ${ }^{107}$

\section{Vernor v. Autodesk, Inc. (9th Circuit panel)}

While the Vernor district court's approach to copy ownership will be heralded in this Article as perhaps the best analysis of the precedents to date, the Ninth Circuit panel that reversed the district court committed nearly every error this Article warns about as it adopted a narrow version of the Agreement Controls approach.

Timothy Vernor sold used comic books, collectibles, and software on eBay, the online auction site. ${ }^{108}$ Vernor purchased several used copies of Autodesk, Inc.'s AutoCAD software from Autodesk's direct customers, and

103. Wall Data Inc. v. L.A. Cnty. Sheriff's Dep’t, 447 F.3d 769, 785 (9th Cir. 2006).

104. MDY Industries, 2008 WL 2757357 , at *8.

105. Id. at $* 9$.

106. Id. at $* 10$.

107. Id. The inherent ambiguity in "licensees of the copies" leads to confusion. See infra Section V.A.1.

108. Appellee's Brief at 1, Vernor v. Autodesk, Inc., 621 F.3d 1102 (9th Cir. 2010) (No. 09-35969), available at $\mathrm{http} / / \mathrm{www}$. eff.org/files/filenode/vernor_v_autodes/Vernor $\% 20$ Appellee $\% 27 \mathrm{~s} \% 20 \mathrm{Br}$.pdf. 
he resold the copies on eBay. ${ }^{109}$ Autodesk sent eBay several notices of claimed infringement asserting that Vernor's online resale of its software infringed Autodesk's copyright. ${ }^{110}$ In response, eBay terminated Vernor's pending sales and eventually shut down his online business, cutting off his primary source of income. ${ }^{111}$

While the district court held that Vernor was an owner of the copies of AutoCAD and therefore entitled to resell them under the first sale doctrine, ${ }^{112}$ the Ninth Circuit reversed, ${ }^{113}$ adopting a new test for determining copy ownership ${ }^{114}$ to "reconcile[]" earlier conflicting precedents. ${ }^{115}$

The Ninth Circuit panel declared,

We hold today that a software user is a licensee rather than an owner of a copy where the copyright owner (1) specifies that the user is granted a license; (2) significantly restricts the user's ability to transfer the software; and (3) imposes notable use restrictions. ${ }^{116}$

The Ninth Circuit's summary of its application of the three-prong test indicates that it regarded the first factor as equivalent to purporting to reserve title to the copy. ${ }^{117}$ Other courts employing an Agreement Controls approach have examined the other two factors. ${ }^{118}$ However, those courts employing an Agreement Controls approach have typically examined the entire agreement, including things such as the period of authorized use, whether return is required, the amount of payment and whether it is periodic, and who bears the risk of loss, among other terms. The Ninth Circuit panel instead takes a narrower approach than any other court applying the Agreement Controls approach and focuses on just the three aspects of the Agreement contained in the citation above.

109. Vernor, 621 F.3d at 1102.

110. Appellee's Brief, supra note 108, at 1.

111. Id.

112. Vernor v. Autodesk, Inc., 555 F. Supp. 2d 1164, 1170-71 (W.D. Wash. 2008), rev'd, 621 F.3d 1102 (9th Cir. 2010).

113. Vernor, 621 F.3d at 1102.

114. Id. at 1110-11.

115. Id.

116. Id. at 1111.

117. Id. at 1112 ("Thus, because Autodesk reserved title to Release 14 copies and imposed significant transfer and use restrictions, we conclude that its customers are licensees of their copies of Release 14 rather than owners.").

118. See supra Section III.A. 


\section{The Uniform COMmercial CODE CONTROLS APproACH}

"The retention or reservation of title by a seller of goods notwithstanding shipment or delivery to the buyer under Section 2401 is limited in effect to a reservation of a 'security interest.' "119

An analogue of the Agreement Controls approach is found in a handful of decisions that are just as formalistic about following the dictates of a given controlling document. But that document is not a particular agreement; it is the U.C.C. itself. This approach tends to arise when courts are more concerned with the goods being transferred and less focused on the copyrighted works that may be embodied in those goods. It also tends to arise when there is no written agreement from which to determine the passing of title, and so some other source of title passage rules are sought. Finally, this approach seems to be more often applied where there is less of a dispute about whether a sale occurred or was attempted, and more of a question of who currently owns the underlying goods.

Section 2-401 of the U.C.C. covers the "Passing of Title" and provides several rules for the passage of title to a good. One of the chief rules is that any retention or reservation by the transferor ${ }^{120}$ of the title in goods shipped or delivered to the transferee is limited in effect to a reservation of a security interest. ${ }^{121}$ That is, in a permanent transfer of a tangible good, reservation of full title is simply not permitted under the U.C.C. ${ }^{122}$ Further, where one pays full price in one lump sum, no security interest exists and the transferee is simply deemed to hold title to goods upon full payment.

119. U.C.C. \1-201(35) (2001).

120. Where the U.C.C. speaks of seller and buyer, this Article will speak of transferor and transferee so as not to bias the discussion, which in many cases is thought of as a question of whether there was a "sale" at all. What the U.C.C. calls a sale, this Article will call a "permanent transfer," as that accurately describes the nature of most so-called "licenses." The aim is to analogize from the U.C.C. principles, not necessarily to claim that they apply as written.

121. U.C.C. \2-401(1) (2001); U.C.C. \1-201(35) ("The retention or reservation of title by a seller of goods notwithstanding shipment or delivery to the buyer under Section 2-401 is limited in effect to a reservation of a 'security interest.' "); In re Telemart Enters., Inc., 524 F.2d 761, 765 (9th Cir. 1975) ("A reservation of title by the seller is to be regarded as reservation of a security interest." (citing UCC \2-401(1))).

122. Autodesk's brief in answer to Vernor's petition to the Ninth Circuit for rehearing en banc argued that the "Unless otherwise explicitly agreed" language of section 2-401(2) would permit reservation of title after sale and delivery. Answer to Petition for Rehearing En Banc at 23, Vernor v. Autodesk, Inc., 621 F.3d 1102 (9th Cir. 2010) (No. 09-35969), available at http://www.scribd.com/doc/43215193. On the contrary, the U.C.C. contemplates that a buyer and seller might vary the timing of title transfer so that it need not always be contemporaneous with physical delivery, but nothing in that section suggests a buyer and seller could agree that title would never transfer, even after a fully completed sale and delivery. 
Another U.C.C. title-passage rule is that, unless otherwise explicitly agreed, title to the goods passes at the time and place at which the transferor completes performance with reference to the delivery of the goods, despite any reservation of a security interest. Title passes upon delivery at destination only if the contract so requires. Otherwise, it passes upon shipment. ${ }^{123}$

Applying these title-passage rules, courts have concluded that the title to a rug containing a copyrighted design passed in accordance with $\int 2$ $401(2),{ }^{124}$ that title to books passed to a buyer upon physical delivery of the books per Idaho Code $\int 28-2-401(2)$ (Idaho's enactment of the relevant U.C.C. section), ${ }^{125}$ and that title to a computer and software was determined pursuant to both California's enactment of the U.C.C., Cal. U. Comm. Code 2401(1)-(3), ${ }^{126}$ and to the District of Columbia's enactment, D.C. Code Ann. $\int 28: 2-401 .^{127}$

\section{THE ECONOMIC REALITIES APPROACH}

"Ownership of a copy should be determined based on the actual character, rather than the label, of the transaction by which the user obtained possession. Merely labeling a transaction as a lease or license does not control." Raymond T. Nimmer (1992). ${ }^{128}$

While the Reservation of Title and the Agreement Controls approaches elevate form over substance, a slight majority of courts have been willing to look beyond the four corners of the agreement and look instead to "the economic realities" of the transaction. The factors considered can include terms of the agreement not related to copyright permissions, as well as facts about the transaction not discussed in the agreement at all.

The leading articulations of the approach come from two Ninth Circuit cases, and an expansion of the approach comes from a Second Circuit case where the court looked beyond formal "title" to determine who was an "owner" under $\int 117$.

123. U.C.C. \$2-401(2) (2001); United States v. Long, 706 F.2d 1044, 1050 (9th Cir. 1983) ("UCC \2-401(2) provides that title passes at the time and place at which the seller completes his performance with reference to physical delivery of the goods.").

124. Classic Concepts, Inc. v. Linen Source, Inc., Nos. 04-8088 \& 04-8457, 2006 U.S. Dist. LEXIS 96767, at*49-50 (C.D. Cal. Apr. 27, 2006).

125. Old West Realty, Inc. v. Idaho State Tax Comm'n, 716 P.2d 1318, 1320-21 (Idaho 1986); see also Skripak v. Comm'r, 84 T.C. 285, 315 (T.C. 1985) (books); Middlebrooks v. Comm'r, 34 T.C.M. (CCH) 1187, at*12-15 (T.C. 1975) (magazines).

126. Mahru v. Superior Court, 191 Cal. App. 3d 545, 549 (Ct. App. 1987).

127. Synergistic Techs., Inc. v. IDB Mobile Commc'ns, Inc., 871 F. Supp. 24, 29 (D.D.C. 1994).

128. Applied Info. Mgmt. v. Icart, 976 F. Supp. 149, 154 (E.D.N.Y. 1997) (citing RAYMOND Nimmer, THE LAW OF COMPUTER TECHNOLOGY \1.18[1], at 1-103 (1992)). 
1. United States v. Wise

Without using the phrase "economic realities," the Ninth Circuit in United States $v$. Wise ${ }^{129}$ nonetheless gave birth to an approach to determining ownership of a copy that looks to such realities of the transaction. The case involved feature-length motion picture prints that were occasionally provided, under various agreements, to "V.I.P.s" described as "prominent member[s] of the motion picture industry or community" and to television studios. ${ }^{130}$

The court looked beyond the failure of some of the agreements to expressly reserve title in the copyright owner and nonetheless found with respect to one of the transactions that "the general tenor of the entire agreement" was inconsistent with the concept of a sale. ${ }^{131}$ The Wise court also wrote that since "copyright proprietors frequently transfer rights in their works by complicated agreements which cannot simply be called 'sales[,]' in each case, the court must analyze the arrangement at issue and decide whether it should be considered a first sale." 132

Analyzing the "arrangement at issue" and looking to the "general tenor of the agreement" led the Wise court to find that some transactions involved sales and others did not. One contract the Wise court considered allowed the actress Vanessa Redgrave to keep possession of the film print "at all times" for her "personal use and enjoyment," but purported to prevent her from transferring the print to anyone else. ${ }^{133}$ The court determined that this contract was a sale despite the purported restrictions on transfer, illustrating that such restrictions on transfer were not dispositive in the Wise court's view. $^{134}$

\section{Microsoft Corp. v. DAK Industries}

Another example of the Economic Realities approach is Microsoft Corp. $v$. $D A K$ Industries. ${ }^{135}$ Here, the Ninth Circuit addressed whether a transaction was "a lump sum sale of software units to DAK" or merely "a grant of

129. 550 F.2d 1180 (9th Cir. 1977), cert. denied, 434 U.S. 929 (1977).

130. Id. at 1184 .

131. Id. at 1191 .

132. Id. at 1188-89 (emphasis added) (citing United States v. Bily, 406 F. Supp. 726, 731 (E.D. Pa. 1975)).

133. Id. at 1192 .

134. Id.

135. 66 F.3d 1091 (9th Cir. 1995); Datalex Ltd. v. PSA, Inc., No. 01-06482, 2003 U.S. Dist. LEXIS 27563, at *6 (C.D. Cal. Jan. 30, 2003) (“"Economic realities' of an exchange determine whether a transaction is a sale, a lease, or a license." (citing DAK Indus., 66 F.3d at 1095)). 
permission to use an intellectual property." "136 The court wrote that "we must look through [this transaction's] form to the 'economic realities of the particular arrangement." "137 Furthermore, "[b]ecause we look to the economic realities of the agreement, the fact that the agreement labels itself a 'license' and calls the payments 'royalties,' both terms that arguably imply periodic payment for the use rather than sale of technology, does not control our analysis." 138

Courts that have addressed the very same question-how to determine if a transaction has resulted in a "sale" despite it bearing a "license" labelhave often ignored $D A K$. $^{139}$ These oversights by subsequent courts were probably the result of the different context. In $D A K$, the Ninth Circuit needed to determine whether a transfer of title had occurred, but not for the purpose of applying the first sale doctrine or for evaluating $\ 117$ rights. Instead, the court needed to make this determination in order to make a finding under the bankruptcy code regarding whether the debt related to this transaction arose prepetition or postpetition. ${ }^{140}$ This is unfortunate because the court provided extensive guidance for determining when a sale has occurred, looking to salient factors about the transaction.

The court noted the following about the transaction:

- DAK's entire debt to Microsoft arose at once at the outset. It was not incurred in installments over time.

- The amount of DAK's payment was calculated based upon quantity of units, not upon duration of use.

- DAK received all of its rights when the term of the agreement commenced, even though payments were made on an installment plan over time, as in the purchase of goods on unsecured credit.

- The timing of the payments was not correlated to DAK's sales of the copies.

- The agreement granted DAK a "right to sell" not "permission to use" the copies.

136. DAK Indus., $66 \mathrm{~F} .3 \mathrm{~d}$ at 1095.

137. Id.

138. Id. (quoting In re Moreggia \& Sons, Inc., 852 F.2d 1179, 1182 (9th Cir. 1988)).

139. DAK Industries was cited in UMG Recordings, Inc. v. Augusto, 558 F. Supp. 2d 1055, 1058 (C.D. Cal. 2008), aff'd, 628 F.3d 1175 (9th Cir. 2011), and SoftMan Products Co. v. Adobe Systems Inc., 171 F. Supp. 2d 1075 (C.D. Cal. 2001), but not by the numerous other cases within the Ninth Circuit discussed herein.

140. DAK Indus., 66 F.3d at 1095. 
- Microsoft did not provide anything at its expense to DAK after the commencement of the agreement. ${ }^{141}$

The court concluded, "[f]or these reasons, the economic realities of this agreement indicate that it was basically a sale, not a license to use."142

It was also likely important to the court that " $t$ the agreement provided that if DAK sold more copies than those paid for by the minimum commitment, DAK would pay Microsoft $\$ 55$ for each additional copy sold. However, if DAK sold fewer copies than those paid for by the minimum commitment, Microsoft would not refund any of the commitment." ${ }^{\prime 13}$ Thus, unlike a situation in which Microsoft might license a manufacturer and distributor to make copies and sell them on its behalf, here the entire risk of loss had been transferred to DAK. One can certainly enter into an agreement where one licenses one's reproduction and distribution rights, such that the same entity can make copies and then sell them on the licensor's behalf. In such a case, the licensor could rightly argue that the licensee has no ownership interest in the copies and that it reserves the right to repossess any not sold. However, $D A K$ 's lesson appears to be that when the licensed distributor pays the copyright owner a fixed amount for a fixed number of copies that cannot be returned if not sold, such a term, perhaps because it transfers the entire risk of loss, transforms a licensing arrangement into a sale of those copies.

\section{Krause v. Titleserv, Inc.: The "Incidents of Ownership"}

In Krause v. Titleserv, Inc., ${ }^{144}$ the Second Circuit pushed the Economic Realities approach a step further than any other court had by rejecting the idea that "formal title" was even necessary for purposes of being an "owner" under $\int 117 .{ }^{145}$ The court wrote in an oft-quoted passage,

141. See id.

142. Id. at 1096 .

143. Id. at 1093.

144. 402 F.3d 119 (2d Cir. 2005).

145. Many courts considering $\mathbb{S} 117$ discuss the legislative history in which the CONTU report had recommended language for the statute that applied to the "rightful possessor of a copy of a computer program." Congress changed the term "rightful possessor" to "owner" but did not explain its reason. Compare FINAL REPORT OF THE NATIONAL COMMISSION ON New Technological Uses of COPyrighted WORKS 12 (1978), with H.R. ReP. NO. 961307, pt. 1, at 23 (1980), reprinted in 1980 U.S.C.C.A.N. 6460, 6482. Some courts have thought this change signified Congress' intent to restrict the application of $\int 117$ to those with full "title" to the copy. In contrast, the Krause court rightly points out that, [t]he term "rightful possessor" is quite broad. Had that term been used, the authority granted by the statute would benefit a messenger delivering a program, a bailee, or countless others temporarily in lawful possession of 
[I] t seems anomalous for a user whose degree of ownership of a copy is so complete that he may lawfully use it and keep it forever, or if so disposed, throw it in the trash, to be nonetheless unauthorized to fix it when it develops a bug, or to make an archival copy as backup security. We conclude for these reasons that formal title in a program copy is not an absolute prerequisite to qualifying for $\int 117(\mathrm{a})$ 's affirmative defense. Instead, courts should inquire into whether the party exercises sufficient incidents of ownership over a copy of the program to be sensibly considered the owner of the copy for purposes of $₫ 117$ (a). The presence or absence of formal title may of course be a factor in this inquiry, but the absence of formal title may be outweighed by evidence that the possessor of the copy enjoys sufficiently broad rights over it to be sensibly considered its owner. ${ }^{146}$

In looking at these "incidents of ownership," the court focused on the following:

Titleserv paid Krause substantial consideration to develop the programs for its sole benefit. Krause customized the software to serve Titleserv's operations. The copies were stored on a server owned by Titleserv. Krause never reserved the right to repossess the copies used by Titleserv and agreed that Titleserv had the right to continue to possess and use the programs forever, regardless whether its relationship with Krause terminated. Titleserv was similarly free to discard or destroy the copies any time it wished. ${ }^{147}$

The court concluded, “Titleserv's right, for which it paid substantial sums, to possess and use a copy indefinitely without material restriction, as well as to discard or destroy it at will, gave it sufficient incidents of ownership to make it the owner of the copy for purposes of applying \117(a).,"148

a copy. Congress easily could have intended to reject so broad a category of beneficiaries without intending a narrow, formalistic definition of ownership dependent on title.

Krause, 402 F.3d at 123 . The Krause court has the better analysis, as courts have only caused mischief by seeking to divine Congressional intent in a situation where nothing definitive is available.

146. Krause, 402 F.3d at 123-24.

147. Id. at 124 .

148. Id. at $124-25$. 


\section{E. The Perpetual Possession APproach}

"If a transaction involves a single payment giving the buyer an unlimited period in which it has a right to possession, the transaction is a sale." Raymond T. Nimmer $(1992,1997) .{ }^{149}$

In opinions from courts ostensibly applying either the Economic Realities approach or the Agreement Controls approach, yet another approach arguably drives the results. Two district court decisions, UMG Recordings, Inc. v. Augusto and Vernor v. Autodesk, Inc. have, intentionally or not, teased this interpretative focus out of the Economic Realities approach to state what this Article calls the Perpetual Possession approach. After explaining this understanding of, or variation on, the Economic Realities approach, Part VI will argue that the Perpetual Possession approach is an excellent development that courts faced with this question should embrace. As the preceding survey of the cases has revealed, courts are in desperate need of a logical approach that respects precedent and congressional choices, and which, in an ideal world, would simply be straightforward for the courts to apply. After this Section provides examples of the Perpetual Possession approach, Part VI argues that the Perpetual Possession approach is such an approach.

\section{UMG Recordings, Inc. v. Augusto}

Troy Augusto made his living selling collectible merchandise on eBay, the internet auction site. ${ }^{150}$ UMG's copyright infringement claim against Augusto was based on his offering "promo CDs" for sale on eBay. ${ }^{151}$ The twenty-six eBay auctions at issue involved authentic CDs lawfully made and distributed by UMG. ${ }^{152}$ Augusto purchased the CDs from retailers in the Los Angeles area or on eBay, but UMG argued that Augusto was not an "owner" of the CDs he bought, because the promo CDs contained one of the two following legends:

149. DSC Commc'ns Corp. v. Pulse Commc'ns, Inc., 170 F.3d 1354, 1362 (Fed. Cir. 1999) (citing RAYMOND T. NIMMER, THE LAW OF COMPUTER TECHNOLOGY 1.24[1], at 1143-44 (3d ed. 1997)); Applied Info. Mgmt. v. Icart, 976 F. Supp. 149, 154 (E.D.N.Y. 1997) (quoting RAYMOND Nimmer, THE LAW OF COMPUTER TECHNOLOGY \1.18[1], at 1-103 (1992)).

150. Appellee's Brief at 1, UMG Recordings, Inc. v. Augusto, 628 F.3d 1175 (9th Cir. 2011) (No. 08-55998), available at http://www.eff.org/files/filenode/umg_v_augusto/ Appellee's Brief.pdf.

151. Id. at 2 .

152. UMG Recordings, Inc. v. Augusto, 558 F. Supp. 2d 1055, 1058 (C.D. Cal. 2008), aff'd, 628 F.3d 1175 (9th Cir. 2011). 
Promotional Use Only-Not for Sale.

or

This $\mathrm{CD}$ is the property of the record company and is licensed for the intended recipient for promotional use only. Acceptance of this CD shall constitute an agreement to comply with the terms of the license. Resale or transfer of possession is not allowed and may be punishable under federal and state laws. ${ }^{153}$

Promo CDs are mailed unsolicited to recipients, typically "music industry insiders who are in a position to provide publicity and exposure" for the CD. ${ }^{154}$ As of the time of this litigation, UMG had never made any efforts to retrieve promo CDs from recipients, and nothing on the packaging of promo CDs indicated that they must ever be returned to UMG. ${ }^{155}$ UMG did not keep permanent records of who received any particular promo $\mathrm{CD}$, and UMG did not take any steps to mark the promo CDs for later tracking. ${ }^{156}$ The district court considered all of these "economic realities" and concluded that "title to the CDs is transferred to the insiders." 157 An authorized disposition of the CDs having occurred, the district court held that UMG's publication right was exhausted, freeing both the recipients of the CDs as well as Augusto to sell them. UMG has appealed to the Ninth Circuit. ${ }^{158}$

The Augusto district court wrote, "[i]n determining whether a transaction is a sale or a license, courts must analyze the 'economic realities' of the transaction. [T] he fact that the agreement labels itself a 'license' . . does not control our analysis." 159

The district court then singled out one factor for special consideration:

The right to perpetual possession is a critical incident of ownership.

Accordingly, the distributor of a copyrighted product's intent to regain possession is strong evidence that the product was licensed,

153. Appellee's Brief, supra note 150, at 13-14.

154. Augusto, 558 F. Supp. 2d at 1058.

155. Id. at 1061. There is evidence that this norm within the promo CD world is changing to include individually watermarked CDs, streaming URLs, listening parties at corporate headquarters, and extensive license language on promotional $\mathrm{CD}$ packaging. Erik Davis, My Data Crime: The Ticking Time Bomb of the Watermarked Advance CD, TECHGNOSIS (Sept. 8, 2007), http://www.techgnosis.com/chunks.php?sec=journal\&cat=noting\&file= chunkfrom-2007-09-08-2341-0.txt.

156. Augusto, 558 F. Supp. 2d at 1061.

157. Id. at 1062 .

158. Id. at $1058,1062$.

159. Id. at 1060 (citing Microsoft Corp. v. DAK Indus., 66 F.3d 1091, 1095 (9th Cir. 1995)). 
not sold, to the recipient. The absence of this intent is strong evidence that the product was sold. ${ }^{160}$

The Augusto district court also found that "perpetual possession" was critical to the Ninth Circuit's decision in Wise, noting that the Wise court did not find a sale when the agreements required a film print's return at the end of a specified period, but did find a sale when the recipient was entitled to keep possession of the film print at all times. ${ }^{161}$

In applying this key factor of a right to perpetual possession to these facts, the district court found that

[h]ere, UMG gives the Promo CDs to music industry insiders, never to be returned. The recipients are free to keep the Promo CDs forever. Nothing on the packaging of the Promo CDs or in the licensing label requires that the recipient return the Promo CDs to UMG. There are no consequences for the recipient should she lose or destroy the Promo CDs-which UMG allegedly considers its property. UMG does not request that any recipients return the Promo CDs and does not otherwise make any affirmative effort to recover possession of the Promo CDs. Further, it appears that UMG could not take these actions; UMG does not keep permanent records identifying who received which Promo CDs. Accordingly, the music industry insiders' ability to indefinitely possess the Promo CDs is a strong incident of ownership through a gift or sale. ${ }^{162}$

Finally, the Augusto district court noted that the only apparent benefit to UMG to claim that it retains title to the copies is as part of an effort to restrain trade by preventing the transfer of its music. However, the court explains that, "[t]his purpose was rejected 100 years ago by the Supreme Court," citing the Court's holding in Bobbs-Merrill. ${ }^{163}$

Thus, by following Ninth Circuit precedent, the Augusto district court highlighted two factors at the heart of the Economic Realities approach: possession and payment. If the right to possession is permanent and the payment ${ }^{164}$ is not correlated to the period of time possessed, then there

160. Id. (footnote omitted) (citing Krause v. Titleserv, Inc., 402 F.3d 119, 123 (2d Cir. 2005) (describing a person's degree of ownership of a copy as complete when he may lawfully use it and keep it forever, or if so disposed, throw it in the trash)).

161. Id. at $1060-61$.

162. Id. (footnote omitted) (citations omitted). The Augusto court also relied on $D A K$ Industries to identify another important factor: the absence of a recurring benefit to the transferor. $I d$.

163. Id. (citations omitted) (citing Bobbs-Merrill Co. v. Straus, 210 U.S. 339 (1908) (rejecting a book publisher's attempt to restrict resale of a book through a label that prohibited sales for less than one dollar)).

164. The $D A K$ Industries court also already noted that nothing should prevent the court from finding that title to the copy has passed to the transferee where multiple payments are 
are strong indicia that title to the copy has passed to the transferee. Conversely, if the possession is expected to be temporary or the payments are correlated to the period of time possessed, then there are strong indicia that title to the copy remains in the transferor.

The importance of these critical indicia of ownership lurked in the background of the Ninth Circuit's key precedents on ownership of copies for decades, ${ }^{165}$ but the Augusto district court's opinion placed them in sharper relief and thereby illustrated a way forward for future courts. ${ }^{166}$

The Augusto district court also did something that is too infrequent in these cases: it considered the relevance of Supreme Court first sale precedents. The courts that have looked to restrictive terms in agreements to reach a result on the question of copy ownership have often made no effort to reconcile enforcement of such provisions with the Supreme Court's refusal to enforce such a restrictive provision in Bobbs-Merrill. Even if there are cases where a relevant distinction can be made, courts should explain such a distinction explicitly.

2. Vernor v. Autodesk, Inc. (district court)

The district court in Vernor had two opportunities to address whether copies of Autodesk's AutoCAD software were sold, first on Autodesk's motion to dismiss and subsequently on cross-motions for summary judgment. ${ }^{167}$ Vernor had acquired the copies at an office equipment sale conducted by an architecture firm, CTA. ${ }^{168}$ In both opinions, the district court found sales that provided Vernor with a first sale defense.

not correlated with period of possession, but instead are more akin to a single fee paid on an installment plan. Augusto itself also illustrates that there need not be payment at all, as in the case of a gift. Instead, the crucial factor is that the copyright holder has voluntarily and permanently parted with its possession of the copy. Cf. 17 U.S.C. \$115(c)(2) (2006) (defining "distributed" in the context of compulsory licenses). An exception to "voluntarily" can even be found in the case of a forced judicial sale.

165. And in the more recent Second Circuit opinion in Krause, 402 F.3d 119.

166. There are, however, certain phrasings in the Augusto opinion that are not ideal, particularly the use of the word "license" which has invited so many past courts to conflate the intangible copyright with the tangible copy. This court avoided that pitfall, but preferably would have written more precisely about title to the copies. Subsequent courts have already begun to apply the Augusto district court's formulation. See F.B.T. Prods., LLC v. Aftermath Records, No. 07-3314, 2009 WL 137021, at*4-5 (C.D. Cal. Jan. 20, 2009) rev'd, 621 F.3d 958 (9th Cir. 2010).

167. Vernor v. Autodesk, Inc. (Vernor I), 555 F. Supp. 2d 1164, 1170 (W.D. Wash. 2008) (on motion to dismiss); Vernor v. Autodesk, Inc. (Vernor II), No. C07-1189RAJ, 2009 WL 3187613, at*11-14 (W.D. Wash. Sept. 30, 2009), rev'd, Vernor v. Autodesk, Inc. (Vernor III), 621 F.3d 1102 (9th Cir. 2010) (on cross-motions for summary judgment).

168. Vernor II, 2009 WL 3187613, at *11-14. 
The Vernor district court reviewed the controlling precedent of Wise and noted the admonition found there that the court "must analyze the 'arrangement at issue and decide whether it should be considered a first sale." "169 After a careful review of the facts, rationale, and holdings in Wise, the district court wrote:

In comparing the transactions found to be sales in Wise with those that were not, the critical factor is whether the transferee kept the copy acquired from the copyright holder. When the film studios required that prints be returned; the court found no sale. When the studios did not require the transferee to return the prints, the court found a sale. Even a complete prohibition on further transfer of the print (as in the Redgrave Contract), or a requirement that the print be salvaged or destroyed, was insufficient to negate a sale where the transferee was not required to return the print. ${ }^{170}$

Applying this guidance from $W$ ise, the Vernor district court wrote:

Taking direction solely from Wise, the court concludes that the transfer of AutoCAD packages from Autodesk to CTA was a sale. Like the Redgrave Contract, the Settlement Agreement and License allowed CTA to retain possession of the software copies in exchange for a single up-front payment. Like the Redgrave Contract, the Settlement Agreement and License imposed onerous restrictions on transfer of the AutoCAD copies. Similar to the salvage transactions in Wise, the License required CTA to destroy the software in the event that it purchased a software upgrade. Under Wise, however, this is a "sale with restrictions on use," and is a sufficient basis to invoke the first sale doctrine. ${ }^{171}$

The Vernor district court also looked beyond the first sale context to those cases that have addressed the copy ownership issue in relation to $\ 117$, and it considered MAI, Triad, and Wall Data. The Vernor district court recognized that these courts were, without citing $W$ ise, looking to restrictive terms in the agreements accompanying a transferred copy to determine whether title to the copy passed. The district court interpreted these cases to reflect an approach that would counsel that the more restrictions found or the more draconian the restrictions are, the less likely it is that title to the copy rests with the transferee. And the Vernor district court acknowledged that, in a comparison of restrictive terms, the Autodesk agreement would fall on the very restrictive end of the comparison as Autodesk's software is

169. Vernor I, 555 F. Supp. 2d at 1169 (citing United States v. Wise, 550 F.2d 1180, 1189 (9th Cir. 1977)).

170. Id. at 1170 (footnote omitted).

171. Id. at 1170-71 (footnote omitted) (citation omitted). 
accompanied by agreements that purport to prohibit the transfer of the software without Autodesk's written permission, among other restrictions.

This placed the district court in the uncomfortable position of having two approaches to addressing the same question, both articulated by the Ninth Circuit at different times, and which, in the present case, led to opposite results. The court tried valiantly to find a means to escape this irreconcilable conflict by considering whether any difference between $\int 109$ and its predecessor statute, $\int 27$ considered in $W$ ise, could be used to distinguish the cases. The court also looked to the fact that Wise was a criminal case, the difference between motion picture film prints and software, and the differences between $\int 109$ and $\ 117$, to see if any of these could provide a basis for resolving the conflict and could place this case more in line with one of these Ninth Circuit precedents. ${ }^{172}$ However, the district court persuasively argued that none of these provided an adequate basis for distinguishing the cases and thus the court was guided by the principle that a subsequent panel of the Ninth Circuit cannot overrule an earlier panel absent intervening Supreme Court precedent or en banc authority. With no such intervening authority, the court was bound to follow Wise. ${ }^{173}$

The district court's opinions in Vernor are carefully reasoned, thorough, and correct in their results. The court achieved this in part through a close reading of Wise, which uncovered the same critical factor that the Augusto court had emphasized: the right to perpetual possession. ${ }^{174}$

\section{THE $A D O B E$ OPINIONS AND INTERPRETIVE DIFFICULTY}

Different interpretive approaches can produce opposite outcomes. The three Adobe opinions provide a unique case study illustrating this point: one court used elements of the Reservation of Title and Agreement Controls approaches and held for the software distributor opposing a first sale defense; the other used the Economic Realities approach and held for the litigant asserting a first sale defense. Both courts were in the Ninth Circuit. No intervening mandatory precedent occurred between the three cases, and

172. Id. at 1173-74; Vernor II, 2009 WL 3187613, at *11-14.

173. Vernor I, 555 F. Supp. 2d at 1172; Vernor II, 2009 WL 3187613, at *11-14.

174. Vernor I, 555 F. Supp. 2d at 1170 ("the critical factor is whether the transferee kept the copy acquired from the copyright holder"); Vernor II, 2009 WL 3187613, at *11-14 ("In each instance in which the transferee could, at his election, retain possession of the transferred copy indefinitely, and the copyright holder had no right to regain possession, the court found an ownership transfer."). 
they involved the same plaintiff attempting to enforce very similar licenses, but nonetheless the two courts reached opposite results. Both courts, even when clearly cognizant of the other's differing point of view, were unable to interpret the same precedent consistently with one another. When the same plaintiff, seeking to enforce essentially the same right over the same three year time period gets different results depending on whether it files its case in Northern or Central California, there is a pressing need for clarification.

Two of these cases were brought in the Northern District of California, both before the Honorable James Ware. ${ }^{175}$ In both cases, Judge Ware used elements of the Reservation of Title and Agreement Controls approaches. He sought to "give effect to the mutual intent of the parties" by looking "exclusively" "at the language of the contract, assuming the language is "clear and explicit." ${ }^{177} \mathrm{He}$ also reasoned that in the event of ambiguity, the court could look to custom and usage of words in the trade to interpret the contract. ${ }^{178}$

In One Stop Micro, the contract, known as the "On Campus Reseller Agreement" ("OCRA"), contained purported restrictions on resellers. For example, the OCRA stated that resellers could not distribute outside their own country, and they were required to take specified steps to ensure that educational purchasers were bona fide members of an educational institution. ${ }^{179}$ The court wrote, "[ $\left.\mathrm{t}\right]$ hese numerous restrictions imposed by Adobe indicate a license rather than a sale because they undeniably interfere with the reseller's ability to further distribute the software." 180

However, finding some sales terminology in the agreement, the court felt the agreement was ambiguous and consulted extrinsic evidence in the form of declarations from individuals familiar with the software industry who largely, and uncritically, reported that industry practice is for software to be "licensed" and not "sold.", 181 This allowed the court to conclude

175. Adobe Sys., Inc. v. Stargate Software Inc., 216 F. Supp. 2d 1051 (N.D. Cal. 2002); Adobe Sys., Inc. v. One Stop Micro, Inc., 84 F. Supp. 2d 1086 (N.D. Cal. 2000).

176. One Stop Micro, 84 F. Supp. 2d at 1090.

177. Id.; see also Stargate Software, 216 F. Supp. 2d at 1055-56 ("The determination of ownership in turn is based primarily on an examination of the OCRA, the agreement between Adobe and its distributors. The Court looks to the language, content, and intent of the OCRA, in determining whether its terms affect a sale or license of the software.").

178. One Stop Micro, 84 F. Supp. 2d at 1090 (citing CAL. CIV. Proc. CODE S 1856(c)).

179. Id. at 1090 n.2.

180. Id. at 1091. Looking to restrictions on rights of distribution in order to determine copy ownership is a specific error that will be addressed infra Part V.

181. Id. at 1091-92. Most of these declarations conflate the intangible copyright with the tangible copy and so are of no benefit. See supra Section II.C; infra Part V. 
that based upon the undisputed evidence submitted by Adobe regarding the intent of the parties in entering into the agreement, trade usage, the unique nature of distributing software, as well as the express restrictive language of the contract, the OCRA is a licensing agreement. Thus, contrary to One Stop's assertions, the OCRA does not represent a first sale between the reseller and Adobe. $^{182}$

In Stargate Software, Judge Ware drew repeated comparisons to his earlier decision in One Stop Micro and found that, "[s]imilar to the OCRA at issue in One Stop, the OCRA in this case contains multiple restrictions that limit the reseller's ability to distribute Adobe's software."183 However, in the intervening year, the Honorable Dean D. Pregerson of the Central District of California had decided yet another Adobe case, SoftMan Products Co., and had found that the transaction there had resulted in a sale of the copy giving rise to a first sale defense. ${ }^{184}$

SoftMan Products Co. ${ }^{185}$ applied the Economic Realities approach to find a sale. The court wrote, "[i]t is well-settled that in determining whether a transaction is a sale, a lease, or a license, courts look to the economic realities of the exchange." 186 The court cited $D A K$ and indicated that the mere "license" label did not control its analysis. The court, citing $\ 202$, also recognized that the question before it was not one of ownership of the copyright, but of "ownership of individual pieces of Adobe software." 187

When examining the transaction's economic realities, the court highlighted the following:

$[T]$ he purchaser commonly obtains a single copy of the software, with documentation, for a single price, which the purchaser pays at the time of the transaction, and which constitutes the entire payment for the "license." The license runs for an indefinite term without provisions for renewal. In light of these indicia, many courts and commentators conclude that a "shrinkwrap license" transaction is a sale of goods rather than a license. ${ }^{188}$

182. One Stop Micro, 84 F. Supp. 2d at 1092.

183. Adobe Sys., Inc. v. Stargate Software Inc., 216 F. Supp. 2d 1051, 1057 (N.D. Cal. 2002).

184. SoftMan Prods. Co. v. Adobe Sys. Inc., 171 F. Supp. 2d 1075 (C.D. Cal. 2001).

185. Id. at 1075.

186. Id. at 1084 .

187. $I d$.

188. Id. at 1085. 
The court also looked to whether risk of loss transferred as an indicator that title had passed. ${ }^{189}$

Ultimately the court distinguished Harmony and explicitly declined to adopt the analysis of One Stop Micro, finding that "a single payment for a perpetual transfer of possession is, in reality, a sale of personal property and therefore transfers ownership of that property, the copy of the software." 190

In an effort to distinguish Stargate Software from SoftMan Products, Judge Ware first noted the unique ease with which software can be copied, making it especially vulnerable to unauthorized copying. He then wrote, ${ }^{191}$

Lastly, as a matter of general principle... the Parties should be free to negotiate and/or set a price for the product being exchanged, as well as set the terms by which the product is exchanged. Fundamental to any free society is the liberty of its members to formulate contracts in accordance with the terms that they agree and consent to mutually execute. "The right

189. Id. ("The distributors pay full value for the merchandise and accept the risk that the software may be damaged or lost. The distributors also accept the risk that they will be unable to resell the product.'); see also supra Section III.D.

190. SoftMan Prods., 171 F. Supp. 2d at 1086. Note the use of the word "perpetual" here, which is an intimation of the Perpetual Possession approach. The court also rejected the holdings of Harmony and One Stop Micro with respect to the applicability of agreements never assented to, because here, SoftMan, as a reseller, never installed the software and thus never assented to any Adobe EULA or other licensing agreement. Id. at 1087-88. The SoftMan Products court noted:

In One Stop, the court stated that although One Stop was not a signatory to an Adobe licensing agreement, it was nevertheless subject to the restrictions of those agreements. 84 F. Supp. 2d at 1092. The court found that by obtaining Adobe software from a party to an Adobe licensing agreement, One Stop was bound by any restrictions imposed by that agreement. Id. at 1093. In Harmony, the court found that "to the extent that defendants bought their Microsoft Products from authorized Microsoft licensees, they were subject to the same licensing restrictions under which those licensees operated." [Microsoft Corp. v. Harmony Computers \& Elecs., Inc., 846 F. Supp. 208, 213 (E.D.N.Y. 1994)] The Court declines to adopt the analysis of these cases.

Id.

191. The paragraphs prior to the one quoted also attempt to distinguish SoftMan Products, but fail. The court first notes that SoftMan Products involved unbundling of a collection of software in apparent violation of a EULA, whereas Stargate Software involved the simple redistribution of Adobe software, as is. Adobe Sys., Inc. v. Stargate Software Inc., 216 F. Supp. 2d 1051, 1058 (N.D. Cal. 2002). While this is a cognizable distinction, the court fails to explain how that distinction would entail that SoftMan Products' transaction resulted in a sale, while Stargate Software's was not a sale. The court then notes that when " 'payment' is made for a particular copy of software, the payment is being made for the value of the objective code that is burned on the CD-ROM," id. at 1059, but fails to explain how this differs from the situation in SoftMan Products, which also involved software burned on CDROMs whose true economic value was derived from that which was embodied within it. See id. at $1058-59$. 
to contract freely with the expectation that the contract shall endure according to its terms is as fundamental to the society as the right to write and to speak without restraint." While exceptions are made in the case of unfair or exploitive contracts, or where an inequitable end results as a result of the agreement, commercial parties are generally free to contract as they desire. $^{192}$

Arguably, this passage exemplifies the Reservation of Title approach, because courts applying it appear motivated by a combination of software exceptionalism and a fervent belief in a nearly unfettered freedom to contract. ${ }^{193}$ Adobe's efforts to control the sale of its software to educational customers was an effort to engage in price discrimination, something that the Stargate Software court saw no reason to obstruct. However, in interpreting the first sale doctrine, the Supreme Court of the United States has written, "whether or not we think it would be wise policy to provide statutory protection for such price discrimination is not a matter that is relevant to our duty to interpret the text of the Copyright Act." 194 Unfortunately, the Copyright Act does not explicitly resolve how courts should determine who is an owner of a copy entitled to $\int 109$ and $\int 117$ rights, and these three Adobe cases vividly illustrate that the approach taken to the resolution of that question can be determinative of the result, making it all the more important that courts employ a consistent and logical approach that respects precedent and Congressional choices. As is discussed in Part III, supra, the Reservation of Title approach over-relies on the terms of the agreement, without giving

192. Id. at 1059 (citations omitted). None of the court's citations were to controlling precedent.

193. It is, however, disconcerting that this policy argument, based upon differences between software and other copyrighted works, should come from the judiciary rather than the legislature. If Congress wishes to recognize a special protection for software distributors it has proven able to do so. See Computer Software Rental Amendments Act of 1990, Pub. L. No. 101-650, 104 Stat. 5134 (codified at 17 U.S.C. \$109(b) (2006)); Sony Corp. of Am. v. Universal City Studios, Inc., 464 U.S. 417, 430-31 (1984). In Sony Corp. of America, the Court noted:

From its beginning, the law of copyright has developed in response to significant changes in technology. Indeed, it was the invention of a new form of copying equipment - the printing press— that gave rise to the original need for copyright protection. Repeatedly, as new developments have occurred in this country, it has been the Congress that has fashioned the new rules that new technology made necessary.

464 U.S. at 430-31 (footnotes omitted). In the absence of such a congressionally authorized distinction, the courts should interpret the relevant copyright statutes as written.

194. Quality King Distribs. v. L’Anza Research Int'l, Inc., 523 U.S. 135, 153 (1998). 
adequate consideration to controlling Supreme Court precedents that require a focus on other factors. ${ }^{195}$

It is useful to reflect on the features we should expect from an interpretative approach to the question of copy ownership, as it will help to confirm the wisdom of the Perpetual Possession approach adopted in Wise and followed in Augusto and Vernor. Thus, the next Part argues for the essential and desirable features of such an approach.

\section{CHARACTERISTICS OF A CORRECT APPROACH TO DETERMINING COPY OWNERSHIP}

Courts are in desperate need of a logical approach to the question of copy ownership that is logically coherent, respects precedent, and respects congressional choices. The Perpetual Possession approach is such an approach.

\section{A. Must Be Logically Correct}

Two logical errors run rampant in the "license versus sale" jurisprudence, but both arise from the same source: a failure to distinguish between the intangible copyright and the tangible copy. First, the word "license" is used in at least two distinct ways, which makes courts susceptible to inadvertent equivocation. Second, mere status as the licensee of a right of copyright is erroneously presumed to be incompatible with also being the owner of a copy. Any approach to determining ownership of a copy must avoid these logical errors. A third error that is at least misguided, if not illogical, is that courts often look to factors that are wholly independent of the question of copy ownership. All three errors must be avoided in a proper approach to determining ownership of a copy of a copyrighted work.

195. I agree with William Patry's comments on One Stop Micro. Patry writes, $[T]$ he court misinterpreted contractual restrictions as indicating the existence of a license agreement for section 109 purposes. Restrictions on the terms of a sale do not by themselves mean a sale has not occurred. If such restrictions are violated, the contract may have been breached, but a sale took place nevertheless and thus no infringement action is available. For example, nothing in plaintiff's agreements gave it a right to call back the copies in the event of a breach. Adobe is, therefore, wrongly decided on the copyright claim. Far too often, courts merely accept plaintiff's description of the transaction as a license.

PATRY, supra note 40, \13:25 (footnotes omitted). 
1. Must Not Equivocate with Respect to the Words "License" or "Software"

When "license" is used as a noun in the copyright context, it means something like, "a grant by the holder of a copyright to another of any of the rights embodied in the copyright short of an assignment of all rights" as in, "The agreement contained a license to reproduce 20 copies of the photograph."

When "license" is used as a verb it typically means "to give permission or consent" as in, "The author licensed her distribution right to the nation's largest distributor."

These uses of the word relate only to the intangible copyright.

The word "license" is also, unfortunately, used in conjunction with tangible things. First, as a noun it is often used synonymously with the terms "agreement" or "contract" when that underlying agreement contains grants of copyright permissions, as in, "Did she sign the license?" This usage does not seem to lead to much confusion and it will not addressed further here.

There is another use of the word "license," particularly in the software context, that is most confusing. Software distributors often say, "We only license our software. We do not sell it." This is a difficult sentence to parse because of the layers of ambiguity involved. However, by reading the relevant case law, ${ }^{196}$ one comes to understand that the intended definition is not just "to give permission or consent" with respect to some right of copyright. It is instead used in a way that means something more like the following:

to transfer to another permanent possession of a tangible object in which a copyrighted work is embodied, without transferring title to the tangible object. ${ }^{197}$

It would be useful to have a different term to indicate this unique use of "license." Something like "no title to the copy" license would perhaps convey the intended meaning, but would be exceedingly cumbersome. For purposes of clarity in this Part, uses of "license" in the sense of "no title to the copy" license will be italicized (license).

Usage of the word license has caused rampant confusion. Before considering some examples of this confusion, it is worthwhile to provide some historical context on the development of this usage of the term license.

196. See supra Part III.

197. This is my own attempt at a definition of "license" as the software distributors use it. 
The Third Circuit explained, in an opinion from 1991, Step-Saver Data System v. Wyse Technology, that:

When these form licenses were first developed for software, it was, in large part, to avoid the federal copyright law first sale doctrine.... [The court describes software rental companies.] The first sale doctrine, though, stood as a substantial barrier to successful suit against these software rental companies, even under a theory of contributory infringement. By characterizing the original transaction between the software producer and the software rental company as a license, rather than a sale, and by making the license personal and non-transferable, software producers hoped to avoid the reach of the first sale doctrine and to establish a basis in state contract law for suing the software rental companies directly. Questions remained, however, as to whether the use of state contract law to avoid the first sale doctrine would be preempted either by the federal copyright statute (statutory preemption) or by the exclusive constitutional grant of authority over copyright issues to the federal government (constitutional preemption). . . . Congress recognized the problem, and, in 1990, amended the first sale doctrine as it applies to computer programs and phonorecords.... This amendment renders the need to characterize the original transaction as a license largely anachronistic. ${ }^{198}$

But the usage, even if anachronistic, has persisted, in part because software distributors wanted more than to defeat the use of the first sale doctrine by software rental companies. Even after Congress responded to that concern, software distributors were unwilling to give up the licensing fiction because it provides a means to other desirable ends such as price discrimination, controlling ancillary markets, and preventing competition in related goods. ${ }^{199}$

The merits of permitting copyright owners these additional benefits are not the focus of this Article. The concern is with how the ambiguous use of the word "license" has created a land mine for courts that end up speaking imprecisely or, in the worst case scenarios, reaching erroneous conclusions.

The Microsoft Corp. v. Software Wholesale Club, Inc. opinion provides one example of the imprecise usage of "license." The court wrote:

198. 939 F.2d 91, 96 n.7 (3d Cir. 1991) (emphasis added) (citations omitted).

199. As an example of price discrimination, most of the Novell and Adobe cases are about educational versions of software offered at a price discounted from the regular retail price. See, e.g., Novell, Inc. v. Unicom Sales, Inc., No. C-03-2785 MMC, 2004 WL 1839117 , at $* 10$ (N.D. Cal. Aug. 17, 2004); Adobe Sys. Inc. v. One Stop Micro, Inc., 84 F. Supp. 2d 1086, 1088 (N.D. Cal. 2000). For anti-competitive examples, Blizzard's terms are designed to prevent third parties from offering competing match-making services for online play and attempt to prevent third-parties from developing independent software that interoperates with Blizzard's software. See Davidson \& Assocs. v. Jung, 422 F.3d 630 (8th Cir. 2005). Thus, the terms aim to give Blizzard sole control of those lucrative markets. 
However, a party that licenses its products rather than selling them may avoid the application of the first-sale doctrine. See, e.g., Harmony Computers \& Elecs., (the fact that Microsoft licenses rather than sells its products likely precludes application of the first-sale doctrine); Novell, Inc., 2000 U.S. Dist. LEXIS 9975, at *7-18 (the first-sale defense applied, but only because Novell sold, rather than licensed, its software product).

What does the phrase "licenses its products" mean here? Both "licenses" and "products" could have two meanings. ${ }^{201}$ If "licenses" refers to a granting of permission with respect to some right of copyright, then it has fallen into the error of ignoring 17 U.S.C. \ 202 by failing to recognize the possibility of ownership of a copy independent from ownership of the copyright. But, if "licenses" instead means licenses - that is, a permanent transfer of possession without a transfer of title to the copy-then one has presumed the answer to the question being asked. In determining whether someone is an owner of a copy, it is not much use to say that those who are not owners of a copy do not have the rights of owners of a copy. This is a tautology. What was wanted was a feature of the transaction that would distinguish the owners from the non-owners, without reference to the label applied by the copyright holder. ${ }^{202}$

The $M A I$ footnote is a paradigmatic example of the logical fallacy of equivocation: "Since MAI licensed its software, the Peak customers do not qualify as 'owners' of the software and are not eligible for protection under $\int 117 ., 203$

The word "software" is used in two different senses within the footnote, making its conclusion a non sequitur. In the second half of the footnote, when the court speaks of owners of "the software" and the applicability of

200. Microsoft Corp. v. Software Wholesale Club, Inc., 129 F. Supp. 2d 995, 1007 (S.D. Tex. 2000) (emphasis added) (citation omitted).

201. Particularly in the software context, we sometimes think of the intangible copyrighted work as the "product." At other times we might refer to the tangible copy on which the work is embodied as the "product." The same ambiguity arises with the word "software" making a "license to use the software" equally, if not more, ambiguous.

202. It might be a logically coherent position to accept that the copyright holder simply can declare that title to the copy is not passing and that no other feature of the transaction matters. However, it would remain unclear where the authority to make such declarations would come from. Even where servitudes are permitted to run with property, public policies impose limits that constrain the would-be creator of such servitudes. See Chafee, supra note 36, at 986-87. It would also be a view with surprising consequences, as there would be some non-owners whose bundle of substantive rights would be identical to those of an owner. Only the handful of courts that embraced the Reservation of Title approach would possibly accept such an argument. However, not everything that is logically coherent is the law or good policy.

203. MAI Sys. Corp. v. Peak Computer, 991 F.2d 511, 518 n.5 (9th Cir. 1993). 
17 U.S.C. \117, the court can only mean "owners of the copy of the software," for $\ 117$ applies only to "the owner of a copy of a computer program." ${ }^{204}$ However, in the first half of the footnote, when the court states that MAI licensed "its software," the court can only mean that MAI licensed "its copyright in its software." This stems from the fact that a "license" is simply a permission granted with respect to an exclusive right, and it is therefore nonsensical to speak of "licensing" a tangible object. ${ }^{205}$ Thus, the footnote should have read, "Since MAI licensed [its copyright in] its software, the Peak customers do not qualify as 'owners' of [the copy of] the software and are not eligible for protection under $\int 117 . "$ But this reading makes explicit that the MAI court has ignored the warning of 17 U.S.C. $\$ 202$, that the exclusive rights of copyright are an entirely separate matter from property rights in any material object.

Thus, there are at least two errors of equivocation that courts must guard against when making a determination of copy ownership. First, the sense in which the word "license" is being used should always be made clear because software distributors use that word to describe a concept far removed from the licensing of copyrights. They instead use it to refer to a wholly uniqueand I will argue, nonsensical—form of permanently transferring a tangible good while retaining title to it. Second, the word "software" and similar words such as "product" must be used in ways that make plain whether one is referring to the intangible copyrighted work or a particular tangible embodiment of that copyrighted work in the form of a copy. Virtually all of the courts utilizing a "magic words" or Reservation of Title approach make one of these errors.

One key to a proper resolution of the "license versus sale" question is a recognition that the two concepts are not mutually exclusive. Consequently, the entire framing of the question as one of "license versus sale" presents a false dichotomy that should be avoided. In a sale, a copy is transferred, the recipient owns the copy, and the recipient is therefore entitled to the benefits of $\int 109$ and $\int 117$. In a license, one must first determine what sense of "license" is intended. If a copyright license is intended, that is, merely a granting of a permission to reproduce, to create derivatives, to distribute, or to publicly perform or display a copyrighted work, then a license of any of these rights can co-occur with a sale of an underlying copy just as easily as with a lease, lending, or rental of the copy. Rather than polar opposites, the concepts of "license" and "sale" are completely independent of one another.

204. 17 U.S.C. $\int 117$ (2006).

205. I further develop this argument in Section V.A.2, infra. 
If instead license is intended, that is, a permanent transfer of a copy of a copyrighted work in which the transferor retains ownership of the copy, then the concepts are mutually exclusive. However, the problem remains that the entire notion of a license is nonsensical. In no other context is anyone even tempted to entertain the view that a permanent transfer of a tangible thing could occur without ownership of the thing passing as well. ${ }^{206}$

\section{Must Recognize the Possibility of Ownership of a Copy Independent from Ownership of the Copyright}

17 U.S.C. $\int 202$ provides that

Ownership of a copyright, or of any of the exclusive rights under a copyright, is distinct from ownership of any material object in which the work is embodied. Transfer of ownership of any material object, including the copy or phonorecord in which the work is first fixed, does not of itself convey any rights in the copyrighted work embodied in the object; nor, in the absence of an agreement, does transfer of ownership of a copyright or of any exclusive rights under a copyright convey property rights in any material object. ${ }^{207}$

206. It is essential that software distributors cling to this fiction of retaining title to the copy even after permanently abandoning the copy to the possession of a customer, because the language of $\int 109$ and $\int 117$ speak in terms of an owner of a copy. If software distributors were to concede that their customers owned their copies but simply owned them subject to the restrictions enumerated in the accompanying license agreement, then the entire aim of evading the exceptions imposed by Congress would be thwarted. Understood in this light, this is not a debate about the enforceability of post-sale restrictions, because the claim software distributors are forced to make is that no sale has occurred at all. The difficulty for software distributors is that they engage in permanent transfers of copies and then seek in vain for a notion of a permanent transfer of possession that is neither a sale nor a gift and implies no transfer of title. I am unaware of such a notion at common law, in the laws governing chattel, or within common sense. Rather, a right to perpetual possession is the hallmark of our notion of an owner. For "owner" to be a distinct concept from that of a bailee or lessee it must contain this right, because a lessee has a temporary, not a perpetual, right of possession, and a bailee has merely lawful possession (and a duty of care), with no right to maintain possession against the bailor's demand. See supra note 34.

207. 17 U.S.C. \202 (2006). The predecessor statute, 17 U.S.C. \ 27 (1958), read similarly:

The copyright is distinct from the property in the material object copyrighted, and the sale or conveyance, by gift or otherwise, of the material object shall not of itself constitute a transfer of the copyright, nor shall the assignment of the copyright constitute a transfer of the title to the material object; but nothing in this title shall be deemed to forbid, prevent or restrict the transfer of any copy of a copyrighted work the possession of which has been lawfully obtained.

Id. Section 41 of the 1909 Act was identical, with the substitution of "this Act" for "this title.” See Copyright Act of 1909, Pub. L. No. 60-349, 』 41, 35 Stat. 1075, 1084 (1909). 
That ownership of the tangible thing is a separate issue from the rights under copyright that one might have with respect to that tangible thing is also a centuries-old principle in U.S. law. The Supreme Court wrote in 1882,

In Stephens v. Cady, ${ }^{208}$ and again in Stevens v. Gladding, ${ }^{209}$ the point decided was that, by a sale of the copperplate engraving of a map on execution from a State court against the owner of the copyright, the purchaser acquired no right to strike off and sell copies of the map.

Mr. Justice Nelson, in delivering judgment in Stephens v. Cady, said:

The copperplate engraving, like any other tangible personal property, is the subject of seizure and sale on execution, and the title passes to the purchaser the same as if made at a private sale. But the incorporeal right, secured by the statute to the author, to multiply copies of the map by the use of the plate, being intangible, and resting altogether in grant, is not the subject of seizure or sale by means of this process ....

This principle has been reiterated many times throughout the years by many diverse courts. ${ }^{211}$ Both the Federal Copyright Statute and the Supreme

208. 55 U.S. 528 (1853).

209. 58 U.S. 447 (1855).

210. Ager v. Murray, 105 U.S. 126, 129-30 (1882) (citations omitted).

211. See United States v. Wise, 550 F.2d 1180, 1187 n.9 (9th Cir. 1977) ("“T]he copyright is distinct from the property which is copyrighted, and the sale of one does not constitute a transfer of the other.”); Local Trademarks, Inc. v. Price, 170 F.2d 715, 718 (5th Cir. 1948) ("A copyright is an intangible, incorporeal right in the nature of a privilege or franchise and is independent of any material substance such as the manuscript or plate used for printing. It is entirely disconnected therefrom."); Harms v. Cohen, 279 F. 276, 281 (E.D. Pa. 1922) (“[A] copyright is an intangible thing, and it is separate and distinct from the material object copyrighted ....”); Werckmeister v. Am. Lithographic Co., 142 F. 827, 830 (C.C.D.N.Y. 1905). The Werckmeister court held:

The author of a painting, when it is finished, before publication, owns a material piece of personal property, consisting of the canvas and the paint upon it. He also owns an incorporeal right connected with it; that is, the right to make a copy of it. These two kinds of property, although growing out of the same intellectual production, are in their nature essentially and inherently distinct. The law has always recognized that they are distinct.... [T] he law has always recognized that a common-law copyright, before a general publication, is a distinct property from the thing to which the copyright applies. One man may be the owner of the thing, and another of the copyright in the thing.

142 F. at 830; see also Patterson v. J. S. Ogilvie Pub. Co., 119 F. 451, 453 (C.C.S.D.N.Y. 1902) (holding that plates sold by sheriff became the property of the purchaser, but gave him no right to publish the copyrighted work which could be printed from them); Werckmeister v. Springer Lithographing Co., 63 F. 808, 812 (C.C.S.D.N.Y. 1894) (holding that author of 
Court have recognized that one could own a tangible thing that embodies a copyrighted work, yet might have no right under copyright to copy, modify, or distribute that copyrighted work.

The Agreement Controls approach, which looks to restrictions on the rights of copyright in an effort to determine title to a copy, must therefore be erroneous. Like Cady and Gladding in the nineteenth century, today one can have permission with respect to none of the rights of copyright and still be an owner of a copy. ${ }^{212}$

\section{Must Not Look to Factors that are Wholly Orthogonal to Resolving the Issue of Copy Ownership}

a) Copyright Permissions are Irrelevant to a Determination of Copy Ownership

One can have permission to reproduce, permission to make derivatives, permission to distribute, and permission to publicly display or perform and yet still not be an owner of the underlying copies. If that is so, and we acknowledge that one could lack any or all of those permissions and not be an owner of a copy, then one's status with respect to these permissions is necessarily independent of one's status as an owner of a copy. Consequently, when one seeks to determine copy ownership, one should not waste time on these irrelevant and potentially misleading questions. One should instead

painting may sell his painting and retain the right to its copyright); Hughes Tool Co. v. Fawcett Pubs., Inc., 315 A.2d 577, 579-80 (Del. 1974). The Hughes Tool court found:

17 U.S.C. \ 27 indicates that a statutory copyright "is distinct from the property in the material object copyrighted."...[A] common-law copyright, like its statutory successor, is distinct from that which is copyrighted. It is not a material substance, but is an incorporeal right in the nature of a franchise or privilege of publication.

315 A.2d at 579-80.

212. Cady and Gladding cannot be distinguished from the software context solely because they involved copperplates from which one would make copies, rather than the copies themselves. The cases following these, cited supra note 211, often involved the very embodiment of the work, such as the painting in Springer Lithographing Co. Additionally, the nature of engravings is such that the copperplates are not treated differently than the copies they produce. Springer Lithographing Co., 63 F. at 809. For example, one could not create duplicate copperplates without permission and avoid liability for infringement of the reproduction right. This principle also reveals a key error of the Federal Circuit's decision in DSC Communicationns Corp. because one could say that Cady and Gladding suffered from rights that were severely limited "in ways that are inconsistent with the rights normally enjoyed by owners" but that had no bearing on whether each held title to the tangible embodiment of the copyrighted work. DSC Commc'ns Corp. v. Pulse Commc'ns, Inc., 170 F.3d 1354, 1361 (Fed. Cir. 1999). 
look for a factor that is dispositive in most or many cases. Consider the following hypotheticals:

Suppose Alice is an amateur photographer hoping to make some money from her hobby. Bob operates a film processing and picture-framing shop in which he also showcases the works of local artists, selling the works to the public on the artists' behalf. If Alice brings film in to have it processed and pays for some requested copies (and nothing more), then it is clear from the nature of such transactions that Bob has Alice's permission to make reproductions from her negatives to create the prints she requests. However, Bob neither owns the copies nor has any other right under copyright. For example, he may not make a derivative work or distribute the prints to others.

Suppose further that one of the services Bob offers is to create an oil painting on canvas from any photograph. Alice might provide one of her photographs to Bob and ask for and pay for such an oil painting, and it would be clear that Bob had permission to make this derivative work. It would also be clear that Bob would not own the copy he created, or have permission to make additional reproductions or distributions.

Bob might also make an arrangement with Alice to frame prints of some of her best work and hang it in his shop for potential sale, charging her a flat price for the framing and splitting the proceeds, if any, from sales of the framed prints. One can imagine such an agreement in which Bob has permission to distribute the work to the public, but in which Alice retains ownership of the framed print if it fails to sell. Bob still has no permission to make reproductions or derivatives.

In each of these cases Bob might have or lack any of the permissions of copyright, and in each case, that fact has no bearing on whether or not Bob owns the underlying copies. When Alice pays for prints or an oil painting, it is understood that she intends to return to take possession of the prints or painting. When she sells framed prints through his shop, she will either return to re-claim possession (retaining ownership) of the framed print in the case of no sale, or will sell the prints outright to Bob for potential resale. The dispositive feature in every scenario is whether or not Bob has a right to perpetually possess the copies. When he lacks that right, he is not the owner of the copies, and if he has that right, then he is.

Courts only create confusion when they look to whether an individual has or lacks certain permissions with respect to the underlying copyright in an effort to determine whether the individual is an owner of the tangible copy. These permissions may vary widely across cases, but they are irrelevant since copy ownership status is determined by an entirely different feature of the transaction. 
b) Particularly Problematic Permissions

Permissions regarding subsequent transfer or distribution are particularly misleading to a determination of copy ownership for purposes of applying the first sale doctrine. Similarly problematic are permissions regarding reproduction and derivative works rights to a determination of copy ownership for purposes of applying $\int 117$ rights. Both types of analysis involve a methodological circular logic problem because rights under $\$ 109$ and $\int 117$ do not require the permission of the copyright owner. If you are an owner of a copy with $\int 109$ rights, then it does not matter what the copyright owner says about distribution as her permission was not needed anyway. If you are an owner of a copy with $\$ 117$ rights, then it does not matter what the copyright owner says about reproducing essential-step copies or preparing adaptations because her permission was not needed anyway. One can also easily imagine lease agreements where one has these permissions regarding transfer, but lacks ownership of the copies. Imagine a service from a DVD rental retailer in which after viewing a rented DVD, you can go to the retailer's website and offer the video to a neighbor for renting. If your neighbor consents, they take over the obligation for any rental fees and for returning the DVD on time and you deliver it to your neighbor. In such a system you would have permission to transfer the copy to someone else, but both you and your neighbor would lack ownership of that copy. Again, one's status with respect to these permissions is wholly independent of one's status as a copy owner, so this feature is not dispositive and simply irrelevant to the question of copy ownership. That the Ninth Circuit panel in Vernor chose this irrelevant factor to be the second of its three factors for determining copy ownership has actually made the utterly confused state of the law worse.

Courts taking the Agreement Controls approach that look to such restrictions on copyright permissions, such as the Wall Data court, make this error. Looking at these features of the transaction tell one nothing dispositive about copy ownership.

\section{B. Must Respect PRECEDENT}

The cases that consider ownership of copies seem particularly prone to ignoring relevant precedents. Courts typically do not explicitly refuse to follow an earlier case's approach, but often ignore those precedents through a failure to cite or discuss them. This may be explained by the wide range of cases in which ownership of a copy can be relevant, such as first sale cases, \117 cases, and even a case primarily addressing a question of bankruptcy 
law. ${ }^{213}$ If the courts search only for those precedents addressing the statute they seek to interpret, they may miss those cases decided under other statutes that address the same underlying issue of ownership of a copy. As the Vernor district court held, however, there is no reason to believe that "owner of a particular copy" means one thing in \ 109 and "owner of a copy" means something different in $\int 117 .{ }^{214}$ Thus, whatever the reason for earlier failings, it should be the objective of any interpretive approach to follow controlling precedents.

In particular, the courts frequently fail to ensure that their holdings are consistent with the existing Supreme Court precedents on this issue, particularly the case widely regarded as establishing the first sale doctrine, Bobbs-Merrill Co. v. Strauss.

\section{Must Respect Supreme Court Precedent and Should Seek to Harmonize Circuit Court Precedents}

In Bobbs-Merrill Co. v. Strauss, the Supreme Court held that while the Copyright Act, then in effect, provided copyright holders with a reproduction and publication right:

$[\mathrm{O}]$ ne who has sold a copyrighted article, without restriction, has parted with all right to control the sale of it. The purchaser of a book, once sold by authority of the owner of the copyright, may sell it again, although he could not publish a new edition of it. ${ }^{215}$

The Bobbs-Merrill Company had printed a notice in a book it published which read:

The price of this book at retail is one dollar net. No dealer is licensed to sell it at a less price, and a sale at a less price will be treated as an infringement of the copyright. ${ }^{216}$

This notice shares many characteristics of the terms found in software licensing agreements that courts are asked to interpret over 100 years later. This fact did not escape the district court in Novell, Inc. v. CPU Distributing, Inc., which wrote,

The Court concludes that whether the EULA is otherwise enforceable or not, it is similar to the notice included in the books published by Bobbs-

213. See Microsoft Corp. v. DAK Indus. Inc., 66 F.3d 1091 (9th Cir. 1995).

214. See Vernor v. Autodesk, Inc., 555 F. Supp. 2d 1164, 1173 n.8 (W.D. Wash. 2008); Vernor v. Autodesk, Inc., No. C07-1189RAJ, 2009 WL 3187613, at *11-14 (W.D. Wash. Sept. 30, 2009), rev'd, 621 F.3d 1102 (9th Cir. 2010).

215. 210 U.S. 339, 350 (1908).

216. Id. at 341 . 
Merrill and, as such, does not preclude a finding that a first sale occurs when Novell delivers the copies of its software to the OEMs. ${ }^{217}$

This is the proper analysis. Given that the Supreme Court has held that Bobbs-Merrill's restrictions were unenforceable, there should at least be an investigation of whether software licensing terms that seek to evade the first sale doctrine are suspect as well. Certainly such terms should not be deferred to as key evidence for the proposition that title to the copy has not passed to the transferee. ${ }^{218}$

Additionally, the courts considering transfers of title should, where possible, not create circuit conflicts. There are a series of "waste paper" and salvage cases that held that even where a copyright holder sold copies of his work to another solely for purposes of destruction, such transactions were nonetheless first sales that could not give rise to copyright infringement when the salvage company sold the copies in breach of the agreement. ${ }^{219}$

217. No. H-97-2326, 2000 U.S. Dist. LEXIS 9975, at*8 n.4 (S.D. Tex. May 4, 2000).

218. The Vernor panel opinion is unsatisfying in this respect. By permitting software distributors to control all subsequent uses of their distributed software, the panel suggests that Bobbs-Merrill needed only to write a better license agreement in order to enforce postdistribution restrictions on its books. See Vernor, 621 F.3d at 1111, 1114. Such an interpretation ignores the extent to which the Supreme Court's holding was animated by concerns over restrictions on the alienability of chattel and by a desire to restrict copyright owners to the narrowly-drawn rights enumerated by the statute. See Bobbs-Merrill Co., 210 U.S. at 350-51. Furthermore, distinguishing between a "notice" in the front of a book and a "license agreement" that accompanies software would be to make a distinction without finding a relevant difference.

219. See United States v. Wise, 550 F.2d 1180, 1193 (9th Cir. 1977) (“[T]here would of course be a 'first sale' of any film sold for salvage.”); United States v. Drebin, 557 F.2d 1316, 1327 (9th Cir. 1977) (assuming sale of film print to a salvage company would constitute a sale for first sale purposes, but finding insufficient evidence that defendants actually purchased prints from salvage companies); United States v. Atherton, 561 F.2d 747, 751 (9th Cir. 1977) ("In a criminal prosecution, a sale for salvage purposes can be a first sale."); Indep. News Co. v. Williams, 293 F.2d 510, 516 (3d Cir. 1961) (holding that coverless comic books sold for use as waste paper could be resold because of the first sale doctrine); Harrison v. Maynard, Merrill \& Co., 61 F. 689, 691 (2d Cir. 1894). The Harrison court held:

[T] he right to restrain the sale of a particular copy of the book by virtue of the copyright statutes has gone when the owner of the copyright and of that copy has parted with all his title to it, and has conferred an absolute title to the copy upon a purchaser, although with an agreement for a restricted use. The exclusive right to vend the particular copy no longer remains in the owner of the copyright by the copyright statutes. The new purchaser cannot reprint the copy. He cannot print or publish a new edition of the book; but, the copy having been absolutely sold to him, the ordinary incidents of ownership in personal property, among which is the right of alienation, attach to it. If he has agreed that he will not sell it for certain purposes or to certain persons, and violates his agreement, and sells to an innocent purchaser, he can be punished for a violation of his 
Again, if these courts were willing to ignore the breach of such a central term of these agreements and nonetheless find a first sale, present day courts that allow litigants to defeat the first sale doctrine through restrictive terms in licensing agreements appear to have the analysis completely backwards. The courts should instead seek to harmonize their decisions with these cases or at least address the cases to explain why they are distinguishable in a given instance. $^{220}$

\section{Should Heed the Warning of the Supreme Court's Recent Quanta Computer Decision}

In Quanta Computer, Inc. v. LG Electronics, Inc., ${ }^{221}$ the Supreme Court reaffirmed the long-standing doctrine of patent exhaustion, and in so doing, included a discussion of how the Court came to reject its holding in Henry $v$. A. B. Dick Co., ${ }^{222}$ which had permitted, in 1912, post-sale restrictions on the use of a patented article.

A. B. Dick Co. sold its patented Rotary Mimeograph machine with a notice attached that read, "LICENSE RESTRICTION. This machine is sold by the A.B. Dick Co. with the license restriction that it may be used only with the stencil paper, ink and other supplies made by A.B. Dick Company, Chicago, U.S.A."223

While the Court upheld this restriction, it did so against vigorous dissent which predicted an uncontrolled multiplication of such license restrictions that would permit contract law to cause the expansion of patent law beyond its intended limits. ${ }^{224}$

The following year, 1913, the Court found an opportunity to limit the A. B. Dick Co. holding in Bauer \& Cie v. O'Donnell. ${ }^{225}$ James O'Donnell was a proprietor of a drug store who refused to honor a restriction placed by Bauer Chemical on packages of its patented "Sanatogen," a water-soluble

\footnotetext{
agreement; but neither is guilty, under the copyright statutes, of an infringement.

$61 \mathrm{~F}$. at 691.

220. This is another failing of the Vernor panel opinion, which distinguished none of these cases. See Vernor, 621 F.3d 1102.

221. 553 U.S. 617 (2008).

222. 224 U.S. 1 (1912).

223. Id. at 11. The A. B. Dick court writes, "the patentee sold its machines at cost, or less, and depended upon the profit realized from the sale of other non-patented articles adapted to be used with the machine, and that it had put out many thousands of such machines under the same license restriction." Id. at 26.

224. Id. at 51-55 (White, C.J., dissenting).

225. 229 U.S. 1 (1913).
} 
albumenoid. ${ }^{226}$ The restriction purported to require all such packages to retail for no less than one dollar. O'Donnell purchased the packages first from Bauer and, after they severed relations with him, from jobbers ${ }^{227}$ and sold them for less than a dollar. O'Donnell indicated that he intended to keep doing so. ${ }^{228}$

There, despite a license "for sale and use at a price not less than one dollar," terms which purported to state that purchase was an acceptance of the conditions, ${ }^{22}$ and terms stating that any violation of the restrictions caused all rights to revert to the patentee, the Court rejected the characterization of the license as "a license to use the invention." 230 Noting that "the patentee had no interest in the proceeds of subsequent sales, no right to any royalty thereon or to participation in the profits thereof" 231 the Court concluded that the

packages were sold with as full and complete title as any article could have when sold in the open market, excepting only the attempt to limit the sale or use when sold for not less than one dollar... There was no transfer of a limited right to use this invention, and to call the sale a license to use is a mere play upon words.... The right to vend conferred by the patent law has been exercised, and the added restriction is beyond the protection and purpose of the act. This being so, the case is brought within that line of cases in which this court from the beginning has held that a patentee who has parted with a patented machine by passing title to a purchaser has placed the article beyond the limits of the monopoly secured by the patent act. $^{232}$

Not content to merely distinguish $A$. B. Dick Co., the Court took the opportunity four years later to explicitly overrule it in Motion Picture Patents Co. v. Universal Film Manufacturing Co. ${ }^{233}$ The Quanta Computer Court's summary of the case will suffice here:

[A] patent holder attempted to limit purchasers' use of its film projectors to show only film made under a patent held by the same company. The Court noted the "increasing frequency" with which patent holders were using

226. See id. at 8 .

227. "Jobbers" are wholesalers who operate on a small scale or who sell only to retailers and institutions, often "by the job.” BLACK'S LAW DICTIONARY, supra note 35, at 840.

228. O’Donnell, 229 U.S. at 9.

229. Compare to today's shrinkwrap and click-wrap agreements.

230. O’Donnell, 229 U.S. at 16.

231. Id.

232. Id. at $16-17$.

233. 243 U.S. 502 (1917). In the interim, on October 15, 1914, Congress enacted the Clayton Antitrust Act, Pub. L. 63-212, 38 Stat. 730, reflecting a similar concern about those with monopolies over-reaching. 
A.B. Dick-style licenses to limit the use of their products and thereby using the patents to secure market control of related, unpatented items.... Observing that "the primary purpose of our patent laws is not the creation of private fortunes for the owners of patents but is "to promote the progress of science and useful arts," (quoting U.S. CONST. art. I, $\int 8, \mathrm{cl} .8$ ), the Court held that "the scope of the grant which may be made to an inventor in a patent, pursuant to the [patent] statute, must be limited to the invention described in the claims of his patent." Accordingly, it reiterated the rule that "the right to vend is exhausted by a single, unconditional sale, the article sold being thereby carried outside the monopoly of the patent law and rendered free of every restriction which the vendor may attempt to put upon it." ${ }^{234}$

The importance of this line of patent exhaustion cases is that their vitality has been affirmed as recently as 2008 by the Supreme Court in Quanta. ${ }^{235}$ The Supreme Court has found all manner of contractual restrictions on the sale and use of a tangible thing embodying a copyrighted or patented invention invalid. Despite this, some software and music CD distributors believe that they have found a magical restriction that can avoid this problem. By adding a contractual restriction that purports to reserve title in the tangible object itself, while allowing every other feature of the transaction to look like a sale (or vending), they believe they have avoided over a century of Supreme Court precedent and Congressional policy. The only thing more surprising than the fact of this hubris is the success they have had in persuading courts to fall for it.

\section{Must Respect Congressional Choices}

Software manufacturers have invented a new form of distributing software that they have named "licensing." Because of alleged essential differences between software and other forms of copyrighted works, these distributors seek a special dispensation from the courts to treat the transactions they engage in as immune from the first sale doctrine. Even if software is uniquely situated with respect to its methods of distribution, this is not a determination for the courts to make. As the Supreme Court has written, "[s]ound policy, as well as history, supports our consistent deference to Congress when major technological innovations alter the market for copyrighted materials. Congress has the constitutional authority and the institutional ability to accommodate fully the varied permutations of competing interests that are inevitably implicated by such new

234. Quanta Computer, Inc. v. LG Elecs., Inc., 553 U.S. 617, 626 (2008) (citations omitted).

235. See id. at 625-30. 
technology." 236 This judicial deference to congressional policy choices should be reflected in at least two ways that are often neglected in discussions of copy ownership. Judicial deference requires a determination of whether: (1) contractual provisions that seek to subvert the limitations and exceptions articulated in $\int 107$ through $\int 122$ are federally preempted; and (2) whether an approach to determining copy ownership could be used that would preserve the national uniformity that copyright law seeks.

D. Must TAke into Account that the Copyright ACt Explicitly

EnUmerates Those Methods of Distribution Within the

EXCLUSIVE RIGHTS OF COPYRIGHT OWNERS AND A DISTRIBUTION

IN Which Title TO THE COPY IS RESERVED IS NOT AMONG THEM.

In \106(3), Congress has given copyright holders the exclusive right to distribute copies or phonorecords of the copyrighted work to the public by:

- sale or

- other transfer of ownership, or

- by rental,

- lease, or

- lending. ${ }^{237}$

Upon looking carefully, the first thing to notice is that an exclusive right to distribute by license is nowhere to be found. Take each enumerated form of distribution in turn. First we have "sale," which is most certainly not what copyright holders mean by license. Then there is "other transfer of ownership," but the key feature of licensing is that ownership of the copy is not transferred. The next two, "rental" and "lease," are synonymous in most contexts, though some distinguish the two on the basis of whether the period of possession is auto-renewing. In either case, they both fundamentally involve a limited period of possession in exchange for consideration. ${ }^{238}$ It is that feature, consideration, that distinguishes the fifth and final recognized method of distribution, "lending." Lending is what libraries and neighbors do, and it is done without payment. But all three of these methods of distribution-rental, lease, and lending-fundamentally involve a limited period of possession. For that reason, none of those three methods of distribution can be what is referred to as a license, because copyright holders

236. Sony Corp. of Am. v. Universal City Studios, Inc., 464 U.S. 417, 431 (1984).

237. 17 U.S.C. $\$ 106(3)$ (2006).

238. That consideration is something less than the full value of permanent possession of the thing rented or leased. 
who use the term license routinely do so in transactions where the copy is provided to the transferee for an unlimited period of possession.

The Copyright Act never granted to copyright holders the exclusive right to distribute by means of license. ${ }^{239}$ So, copyright holders made it up. But what are the consequences of that fact?

One might argue that copyright holders only have the exclusive right to distribute in the five ways specified in the statute. Any other form of distribution is simply not a form of distribution recognized by the Copyright Act or granted exclusively to copyright holders. ${ }^{240}$ Even on this view, the consequences are not immediately clear. Does this mean it is forbidden to distribute by license or simply that copyright holders can do so, but when doing so they will not be exercising one of their exclusive rights under copyright? If the latter, it would seem to be a consequence of that fact that copyright holders would also not be able to make use of the remedies of copyright to prevent such non-copyright based distributions. That is, if distribution by license is not one of the exclusive rights granted to copyright holders, then anyone can do it without infringement of any right of the copyright holder! This would be a puzzling transaction because, assuming a first distribution by license, the licensee would, perhaps while acknowledging that he holds no title to the copy, offer to license the copy to another, which, since he could pass no greater right than he held, would amount to a mere transfer of possession and nothing more. Arguably this might violate some contractual provision of the first exchange, but ex hypothesi it could not violate any right of copyright. ${ }^{241}$

239. This is a statement that sounds strange only if one fails to keep the specific definition of license that is under consideration in mind.

240. This argument could rely in part on the choice made by Congress to narrow the publication right which had previously used the phrases "publish" and "vend." The old terminology had forced courts to attempt to interpret the scope of "vend" in particular. In the 1976 Act, Congress clarified by enumerating the methods of distribution it intended to grant exclusively to copyright holders. This strict reading of the statute receives some support from the dissent in Hotaling v. Church of Jesus Christ of Latter-Day Saints, 118 F.3d 199 (4th Cir. 1997) (Hall, J., dissenting). Judge Hall argued:

The owner of a copyright does not possess an exclusive right to "distribute" the work in any conceivable manner; instead, it has the exclusive right "to distribute copies... of the copyrighted work to the public by sale or other transfer of Id. at 205 . ownership, or by rental, lease, or lending."

241. An assumption, for the sake of this bizarre scenario, is that the licensee does not purport to grant any of the actual rights of copyright of the copyright holder, such as the right to reproduce or prepare derivative works. 
One problem with this scenario is that nothing about the transaction would appear any different from a $\$ 106(3)$ distribution. If the licensee offered it on a perpetual basis, it would look in every respect like a sale or other transfer of ownership, and if the licensee offered it for a limited period of time, it would look either like a rental/lease or lending, depending on whether consideration was received. This is, of course, precisely the problem with distribution by license in the first instance by the copyright holder. The copyright holder wishes to insist that it is not an exercise of the distribution right that gives rise to the first sale doctrine, but, in those cases where there is a right of perpetual possession, the transaction looks in every relevant respect like a sale or other transfer of ownership.

Approaching the problem from another angle, we should agree that either distribution by license is an exercise of the distribution right or it is not. If it is not, then we have the problems described above: anyone can do it without infringing. This is clearly unacceptable, at least to copyright holders. However, if distribution by license is an exercise of the distribution right, then the first sale doctrine should apply. That is the overriding purpose of the first sale doctrine: Congress gives the copyright holder one exercise of the distribution right and after that, the right is exhausted and the first sale doctrine takes over. Thus, advocates of the licensing paradigm face a dilemma: either it fails in its purpose because the first sale doctrine still applies or it fails in its purpose because the recipient is free to pass the copy along to another without infringing an exclusive right of the copyright holder.

If this sounds absurd, then recall how we got here. We were faced with two options: either distribution by license is forbidden or it is not. If it is forbidden, then all the questions of copy ownership are solved. If it is not forbidden, then given that it is not among the enumerated rights of copyright holders, what are its consequences? And we found the consequences are certainly not what copyright holders would hope and are in fact borderline absurd. In order to get the result that they desire, defenders of distribution by license would have to argue both that copyright holders are entitled to distribute by means not enumerated in the Copyright Act and that they are entitled to exclude others from doing the same. That is, they have an exclusive right that is not enumerated. If this is the argument defenders of distribution by license are forced into, then things have not gone well for them 
at all. Such unenumerated exclusive rights would pose serious due process problems. $^{242}$

Even without fully developing the above argument, it is apparent that the better view is that distribution by license, since it is not among the methods of distribution enumerated in $\int 106(3)$, is not recognized and not available. That is, there is simply no such thing as distribution of a copy by means of a license. Instead, every transaction falls into one of two categories: those that provide perpetual possession are sales or other transfers of ownership (e.g., gifts) and those that provide a limited period of possession are either a rental/lease or a lending, depending on whether consideration is required. In the case of copies of software and music, those transactions that fall into the sale or gift category provide first sale rights and those transactions that fall into the lease or lending category do not. As a peripheral benefit, such a view provides enormous administrative simplicity, because nearly the only fact about a transaction that matters to determining copy ownership is whether it allows for a right of perpetual possession. ${ }^{243}$

242. Baggett v. Bullitt, 377 U.S. 360, 367 (1964) (“[A] law forbidding or requiring conduct in terms so vague that men of common intelligence must necessarily guess at its meaning and differ as to its application violates due process of law.").

243. One could critique this view by arguing that software distributors could get nearly all of the benefits of distribution by license by simply leasing software for thirty- or fortyyear terms, something clearly less than the copyright term but clearly beyond the software's useful life. The argument would continue that if this is so, then there is no reason to object to distribution by license. On the contrary, I believe courts could reject sham leases just as they have rejected "license labels." There would also be tangible consumer benefits if software distributors were required to label their transactions accurately. Courts could reasonably imply a warranty of merchantability for the period of the lease and refuse to recognize sham lease periods that purport to run beyond the "end of life" or "support lifecycle" of the software. At least one court has already recognized this potential equivalence. Datalex Ltd. v. PSA, Inc., No. 01-06482, 2003 U.S. Dist. LEXIS 27563, at *7 (C.D. Cal. Jan. 30, 2003) ("Due to the rapid changes in technology, which outdates nearly all computer software and hardware every few years, having a 5-year license may well be the same as a perpetual purchase, due to the limited lifetime of any software purchase.”). Once lease periods were constrained to realistic usage periods, consumers would benefit from the clarity provided by calling the transaction what it is and presumably from the lower prices that accompany leases when compared to sales. A purported requirement of return at some distant future date should also be interpreted as a lease or sham lease (i.e., sale) regardless of how the transaction is labeled. 


\section{Must Recognize the Limiting Role Played by $\iint 107$ Through 122 and Examine Whether Contrary Contractual Provisions are Federally Preempted}

The rights of copyright enumerated in 17 U.S.C. \106 are "Subject to sections 107 through $122 \ldots$..244 This language sets up a structure through which a list of the rights of copyright will be enumerated in $\ 106$, but the precise scope of those rights can only be determined by reading $\int 106$ in conjunction with the limitations and exceptions in \$S 107 through 122.

When one of these limitations is found to apply, it does not represent an "excused" infringement of a $\int 106$ right, but rather indicates that the $\$ 106$ right at issue never extended that far to begin with. Congress has carefully chosen the contours of these rights, and courts should raise doubts about the ability of one party to a typically un-negotiated contract of adhesion between parties of unequal bargaining power to re-draw these lines that Congress has chosen. At a minimum, it seems erroneous to look at whether an agreement purports to limit the permissions given with respect to the rights of copyright in an effort to determine whether the licensee has rights Congress put beyond the control of the copyright holder to begin with.

The point may be best expressed by way of an example from another context. Imagine trying to determine whether individuals could make a fair use of a work under $\int 107$ by looking to any agreements accompanying the copyrighted work to see if there were terms in the agreement that restricted the recipient's fair use rights. It would be a bizarre methodology that would entitle every copyright holder to simply do away with the fair uses of his work by fiat. Congress could never have intended that result. ${ }^{245}$ Nonetheless, courts routinely accept a similar methodology when trying to determine if individuals have first sale rights under $\int 109$ or "essential step" rights under $\$ 117$. Courts would reach better results if they thought of $\int 109$ and $\int 117$ as specific fair uses that Congress felt so important that it decided to articulate them separately, rather than simply relying on $\$ 107$ to cover these cases.

244. 17 U.S.C. $\int 106$ (2006).

245. It would also raise constitutional issues under the First Amendment, but those are not the focus here. The handful of decisions that have suggested that a consumer may contract away fair use rights through a click-wrap were wrongly decided. See, e.g., Davidson \& Assocs. v. Jung, 422 F.3d 630, 639 (8th Cir. 2005); Bowers v. Baystate Techs., Inc., 320 F.3d 1317, 1325-26 (Fed. Cir. 2003). The better view is found in Judge Dyk's opinion in Bowers and in other decisions. See Bowers, 320 F.3d at 1335-38 (Dyk, J., concurring in part and dissenting in part); Vault Corp. v. Quaid Software Ltd., 847 F.2d 255, 268-70 (5th Cir. 1988). 
Seen through that lens, the approaches taken by many courts on this issue leave much to be desired.

A full discussion of whether such contractual arrangements are federally preempted is beyond the scope of this Article. Briefly, when the Step-Saver Data court provided its useful history of how the software industry came to "license" but not sell copies of its works in an effort to avoid the reach of the first sale doctrine, it noted, "Questions remained, however, as to whether the use of state contract law to avoid the first sale doctrine would be preempted either by the federal copyright statute (statutory preemption) or by the exclusive constitutional grant of authority over copyright issues to the federal government (constitutional preemption)."246

But while the rental of software that concerned the industry was addressed by Congress, the courts have not seriously taken up the other questions posed by the Step-Saver Data court, as none of the courts to address this issue have a substantive discussion of federal preemption and only a handful mention it at all. ${ }^{247}$

Courts have, in the past, found the scope of federal preemption to be quite broad in the copyright context. The Supreme Court wrote:

These [patent and copyright] laws, like other laws of the United States enacted pursuant to constitutional authority, are the supreme law of the land. When state law touches upon the area of these federal statutes, it is "familiar doctrine" that the federal policy "may not be set at naught, or its benefits denied" by the state law. ${ }^{248}$

Similarly, another court has noted, "even apart from Section 301, the general proposition pertains in copyright law, as elsewhere, that a state law is

246. See Step-Saver Data Sys. v. Wyse Tech., 939 F.2d 91, 96 n.7 (3d Cir. 1991) (citations omitted).

247. Vault Corp., 847 F.2d at 269-70; SoftMan Prods. Co. v. Adobe Sys. Inc., 171 F. Supp. 2d 1075, 1083 n.10 (C.D. Cal. 2001) (citing Step-Saver Data, 939 F.2d at 96 n.7); Foresight Res. Corp. v. Pfortmiller, 719 F. Supp. 1006, 1010 (D. Kan. 1989) (citing Vault, 847 F.2d at 268-70).

248. Sears, Roebuck \& Co. v. Stiffel Co., 376 U.S. 225, 229 (1964) (quoting Sola Elec. Co. v. Jefferson Elec. Co., 317 U.S. 172, 173, 176 (1942)); see also Bonito Boats v. Thunder Craft Boats, 489 U.S. 141, 168 (1989). The question courts should address is whether Congress, in enacting $₫ 107$ through $₫ 122$ has determined that these limitations are among those within the national interest that cannot be set at naught. Unfortunately, courts have done too little to develop this line of inquiry. See David Nimmer, Elliot Brown \& Gary N. Frischling, The Metamorphosis of Contract into Expand, 87 CALIF. L. REV. 17, 41 (1999). 
invalid that 'stands as an obstacle to the accomplishment of the full purposes and objectives of Congress." "249

The precise contours of this preemption can only begin to be determined if a court takes up the question of whether the license agreement that it typically would take at face value "stands as an obstacle to the accomplishment of the full purposes and objectives of Congress" 250 or "sets at naught" a federal policy embodied in the Copyright Act. ${ }^{251}$

\section{Should Preserve as Far as Possible the National Uniformity Copyright Law Seeks}

The Second Circuit in Krause provided an argument that it put forward as a reason against interpreting $\ 117$ (a) to require formal title, but which is also an argument against using an Agreement Controls approach to determining copy ownership. ${ }^{252}$ The Krause court explained that if we must look to the agreement to determine ownership of title, then we must invariably interpret that agreement. When courts interpret agreements, they tend to look to the governing law clause which then leads them to adopt the varying interpretative canons of construction of each state. This leads to conflict with the Copyright Act's "express objective of creating national, uniform copyright law by broadly preempting state statutory and common-law copyright regulation." 253 The Perpetual Possession approach, by focusing almost exclusively on the term of possession, provides an approach that does not pose such conflicts with congressional will.

Alternatively, courts could develop a consistent federal common law approach to the question of copy ownership by more explicitly adopting the U.C.C.'s passage of title rules. Many courts have concluded that the sale of software is a sale of goods governed by the U.C.C. or a given state's implementation of the U.C.C. ${ }^{254}$ The critical question in copy ownership cases is a determination of the owner of a tangible good. This is a subject that is directly addressed by the U.C.C, which reflects an extensive experience

249. Facenda v. N.F.L. Films, Inc., 542 F.3d 1007, 1028 (3d Cir. 2008) (citing 1 NimmeR ON COPYRIGHT \ 1.01[B][3][a] (2008)).

250. Id.; Nimmer et al., supra note 248, at 40-41. (quoting Hines v. Davidowitz, 312 U.S. 52, 67 (1941)).

251. Sola Elec. Co., 317 U.S. at 176.

252. Krause v. Titleserv, Inc., 402 F.3d 119, 123 (2d Cir. 2005).

253. Id. (citing Cmty. for Creative Non-Violence v. Reid, 490 U.S. 730, 740 (1989)); see also 17 U.S.C. S 301(a) (2006).

254. See, e.g., Mark Lemley, Intellectual Property and Shrinkwrap Licenses, 68 S. CAL. L. REV. 1239, 1244 n.23 (1995) (collecting cases); Note, Computer Programs as Goods Under the U.C.C., 77 MICH. L. REV. 1149 (1979). 
with such commercial transactions. Thus, whether federal common law or some other rule governs the transfer of title in copies of copyrighted works, such a scheme should at least be informed by the approach taken by the U.C.C. ${ }^{255}$

The U.C.C.'s rules for the passing of title suggest by analogy that consumers purchasing copies of software should be deemed to receive title to the copies at the time and place at which the copyright owner (or its retailer) completes performance by delivering the copy. ${ }^{256}$ Furthermore, any purported reservation of title to the copy should be limited to a reservation of a security interest. Where a consumer pays full price in one lump sum, no security interest would exist and the consumer should simply be deemed the owner of the copy immediately upon full payment.

Furthermore, the sale of tangible goods such as watches, bottles of shampoo, or boxes of diapers are precisely the sorts of things governed by Article 2 of the U.C.C. However, these tangible goods can also embody or contain a copyrighted work. ${ }^{257}$ Since not every watch, shampoo bottle, or box of diapers contains a copyrighted work, we have a situation where ownership of some tangible goods might be determined solely by reference to the U.C.C. principles in section 2-401. Conversely, ownership of other tangible goods containing copyrighted materials might be determined by any one of the other approaches described in this Article, depending upon the court. Those courts that apply approaches that are extremely deferential to the copyright owner will reach results that yield whatever ownership status the copyright owner prefers, which may well be at odds with the result U.C.C. section 2-401 would have counseled. Such contradictory results are extremely unsatisfying, suggesting that harmonizing the federal common law regarding transfer of title to copies of copyrighted works with the U.C.C.'s title-passing principles would be far more sensible.

This Article advocates for the Perpetual Possession approach, but at least one understanding of a U.C.C. Controls approach could yield equivalent results. Section 2-401 basically does not permit a reservation of title, and thus

255. United States v. Ravel, 930 F.2d 721, 725 (9th Cir. 1991) (noting that the U.C.C. may be relevant to the import of a term used in a federal statute); Sierra Pac. Indus. v. Lyng, 866 F.2d 1099, 1110 n.16 (9th Cir. 1989) ("Federal courts frequently draw upon the Uniform Commercial Code in creating federal common law.”).

256. See supra Section III.C.

257. See Quality King Distribs. v. L'Anza Research Int'l, 523 U.S. 135 (1998) (shampoos, conditioners, and other hair care products with copyrighted labels affixed thereto); Omega S.A. v. Costco Wholesale Corp., 541 F.3d 982 (9th Cir. 2008) (watches with copyrighted engraving on back); Denbicare U.S.A. Inc. v. Toys "R" Us, Inc., 84 F.3d 1143 (9th Cir. 1996) (diapers in copyrighted packaging). 
under both approaches, when a permanent transfer occurs, a right of perpetual possession exists, and a sale is deemed to have occurred.

\section{HOW TO ADDRESS MDY INDUSTRIES LLC V. BLIZZARD ENTERTAINMENT, INC.}

Purchasers of Blizzard's World of Warcraft ("WoW") pay a single amount up front for the client software, and nothing in Blizzard's EULA or TOU reflect a requirement that WoW purchasers return the software to Blizzard after any specified period. It is theirs to keep, destroy, or give away for as long as they like. Under the Perpetual Possession approach, this leads to the conclusion that WoW purchasers are owners of their copies. As owners of copies, they are entitled, under $\int 117(\mathrm{a})(1)$, to make another copy of WoW, provided that such a new copy is created as an essential step in the utilization of WoW in conjunction with a machine and that it is used in no other manner. ${ }^{258}$ When an owner of a copy of WoW runs WoW in conjunction with Glider, a RAM copy of portions of WoW is created as an essential step in the utilization of WoW in conjunction with their computer. ${ }^{259}$ That RAM copy is used in no other manner. The creation of the RAM copy is an essential step in the utilization of WoW in conjunction with the user's computer because the creation of RAM copies is an automated process that necessarily occurs in the utilization of any program. WoW simply could not be utilized at all in conjunction with a computer without the creation of a RAM copy, making its creation an "essential step" in its utilization. The RAM copy is used in "no other manner" because Glider is not a cracking or copying tool that enables the creation of copies. ${ }^{260}$

Thus, if WoW users were entitled to make RAM copies of WoW under $\int 117$, then even if such users breached their agreement with Blizzard with respect to using bots, they were not direct infringers of Blizzard's copyright. Consequently, MDY Industries is not liable for secondary infringement. This result is reasonable because it is profoundly odd that assisting someone to break the rules of a game would constitute secondary copyright infringement.

258. 17 U.S.C. $\$ 117(a)(1)(2006)$.

259. It is probably never the case that the entirety of a complex software program, such as WoW, is in a user's RAM simultaneously, but instead, primarily those portions necessary for operating the software at that moment are in RAM. Whether these serially-present snippets of the program in RAM should even be considered a "copy" or "fixed" are further issues worthy of careful reflection. For the purposes of this argument, I will refer to what is created in RAM as a "copy."

260. The "no other manner" requirement seems motivated by an interest in preventing the creation of infringing copies. The interpretation of each of the elements of $\int 117$ are adeptly addressed at length in Krause v. Titleserv, Inc., 402 F.3d 119, 125-30 (2d Cir. 2005). 
No one likes cheaters, but Blizzard has alternative methods of dealing with bots, and could adopt a "carrot and a stick" approach. It could offer the carrot of creating alternative Battle.net server networks where bots are allowed, and utilize the stick of continuing to terminate users who use bots on servers where they are not allowed. Blizzard also has the ability to terminate the Battle.net account of a user violating the terms of that service, forcing them to sacrifice the remainder of the month's service already paid for, and could also use authorization codes with the client software, forcing banned users to purchase another copy of WoW in order to play again. The cost to users of new Battle.net accounts and new authentication codes would be a strong deterrent to repeat botting, especially where alternative networks existed where it was allowed.

\section{CONCLUSION}

To determine whether title to a copy has been transferred, courts should look to whether the transferee has a right of perpetual possession of the copy. This is the key factor that distinguishes sales and gifts on the one hand, and leases and lending on the other. The invented notion of "licensing" software, where that means transferring perpetual possession of a copy but retaining title to the copy, is both incoherent and not found in the Copyright Act. Courts that look to the agreement accompanying a copy are focusing on the wrong factors for determining ownership of the copy, unless they stay focused on the right of perpetual possession, as the controlling precedents in both the Ninth and Second Circuits say that they should. Where other courts have gone astray, the Augusto and Vernor district courts found the correct path and demonstrated an approach that is logical, that respects controlling precedent and congressional choices, and that is easy to apply yielding results that square with settled consumer expectations. Thus, the Augusto and Vernor district court opinions show us not only how to resolve MDY Industries, but also the question of copy ownership in many future cases. 